\title{
Õpilaste loodusteadusliku kirjaoskuse tasemete muutus gümnaasiumiõpingute jooksul
}

\author{
Miia Rannikmäe ${ }^{\mathrm{a} 1}$, Regina Soobard ${ }^{\mathrm{a}}$, Priit Reiska ${ }^{\mathrm{b}}$, \\ Arne Rannikmäe ${ }^{c}$, Jack Holbrook ${ }^{\mathrm{a}}$ \\ ${ }^{a}$ Tartu Ülikooli loodusteadusliku hariduse keskus \\ ${ }^{b}$ Tallinna Ülikooli loodus- ja terviseteaduste instituut \\ ' Sisekaitseakadeemia õigus- ja sotsiaalteaduste keskus
}

\begin{abstract}
Annotatsioon
Uurimuse eesmärk on longituuduuringule tuginedes kirjeldada gümnaasiumiõpilaste loodusteadusliku kirjaoskuse kujunemise protsessi dünaamikat. Töös kasutatud originaalinstrument koosneb neljast osast: neljast kontekstipõhisest ülesandest, teaduse olemuse ja enesehinnangu küsimustikest ning mõistekaardist. Representatiivse valimiga uuringus osalesid õpilased 42 koolist. Uurimistulemustest ilmneb, et õpilaste loodusteadusliku kirjaoskuse tase kasvab gümnaasiumi jooksul minimaalselt. Õpilaste tulemused 10. ja 12. klassis on sarnased nii aineteadmiste reprodutseerimises, kõrgemat järku kognitiivsetes oskustes, teaduse olemuse mõistmises, enesehinnangus ja ka mõistekaardi kasutamises. Seega, kuigi õppekava on kompetentsuspõhine, näitavad uurimistulemused, et õpilaste loodusteadusliku kirjaoskuse taseme muutus tuleneb pigem aineteadmiste juurdekasvust kui muudest komponentidest. Seetõttu on vaja alustada hariduspoliitilist diskussiooni loodusteaduslike õppeainete õpetamise nüüdisajastamiseks.
\end{abstract}

Võtmesõnad: loodusteaduslik kirjaoskus, kontekstipõhine hindamine, mõistekaardi meetod, teaduse olemus

\section{Sissejuhatus}

Viimasel kümnendil on palju uuritud 14-15aastaste õpilaste saavutusi loodusteadustes, samuti õpilaste suhtumist loodusteaduslike õppeainete õppimisse (Murcia, 2009; Tytler, 2014). PISA testide põhjal on Eesti põhikooliõpilaste tulemused loodusteaduslikes õppeainetes jätkuvalt heal

Loodusteadusliku hariduse keskus, Tartu Ülikool, Vanemuise 46, 51014 Tartu; miia.rannikmae@ut.ee 
tasemel. Enamik õpilastest saavutab PISA loodusteadusliku kirjaoskuse 3. ja 4. taseme. Muu hulgas tähendab see õpitu rakendamist nii tuttavas kui ka õpitust erinevas kontekstis (koos lisaselgitustega) (OECD, 2007, 2016). Eesti 15aastaste õpilaste tulemustest kahel kõrgeimal PISA saavutustasemel (5. ja 6. saavutustase) ilmneb, et uuringu kavandamises saavutab need tasemed 14,5\% õpilastest, nähtuste teaduslikus selgitamises 13,8\%, andmete ja tõendusmaterjali teaduslikus tõlgendamises $15,8 \%$, sisuteadmistes $14,2 \%$ ning teadmistes protseduuridest ja teaduse olemusest $14,3 \%$ õpilastest (OECD, 2016). Tulemustest järeldub, et kuigi enamik Eesti õpilastest jõuab 3. ja 4. saavutustasemele, on kahel kõrgeimal tasemel vähem neid õpilasi, kes suudavad tunnis omandatud teadmisi ja oskusi rakendada õpitust erinevas kontekstis. Siinkohal tekib küsimus, kas õpingute jätkudes gümnaasiumis kujundatakse neid oskusi sihipäraselt edasi ja kas võrreldes põhikooli lõpuga on gümnaasiumis rohkem kõrgema loodusteadusliku kirjaoskuse tasemega õpilasi ning kuidas vastavad koolilõpetajate oskused tööandjate soovidele.

Rahvusvahelised võrdlusuuringud eelnimetatud teemal gümnaasiumiastme õpilaste kohta seni puuduvad. Paljudes riikides on selle kooliastme õpilastel võimalik valida, mis mahus ja mis loodusteaduslikke õppeaineid õppida. Seetõttu on raske kavandada valiidseid võrdlusuuringuid aineteadmiste omandamise kohta. Samas on üksikuid teadusuuringuid, mis selgitavad gümnaasiumiastme õpilaste hoiakuid ja enesehinnanguid loodusteaduslikes õppeainetes kujundatavate teadmiste ja oskuste suhtes (Choi, Lee, Shin, Kim, \& Krajcik, 2011). On loodud ka mitmeid mudeleid ja instrumente, mille alusel saab iseloomustada gümnaasiumiastmes omandatud teadmisi ja oskusi, sh sotsiaal-teadusliku põhjendamise oskust (Griffin, Care, \& McGaw, 2012; NGSS, 2013; Romine, Sadler, \& Kinslow, 2017).

Ühiskonna kiire areng seab õpilastele teadmiste ja oskustega seoses uued nõudmised (Holbrook, 2008). Tänapäeva täisväärtuslik kodanik valdab teadmisi ja oskusi, millest paljusid saab kokku võtta mõistega loodusteaduslik kirjaoskus (Choi et al., 2011; Holbrook \& Rannikmäe, 2009; OECD, 2016). Loodusteaduslik kirjaoskus sisaldab eri dimensioone, sh kognitiivset, afektiivset ja metakognitiivset dimensiooni (viimane märgib oskust hinnata oma oskuste taset). Nende dimensioonide hindamiseks on vaja asjakohaseid mõõteinstrumente, mis võimaldavad teha järeldusi õpilaste loodusteadusliku kirjaoskuse taseme kohta gümnaasiumi lõpus ning anda tagasisidet Eesti kompetentsuspõhise õppekava rakendumise kohta (Soobard, 2015). Selle oskuse kujundamine on ka Eesti põhikooli ja gümnaasiumi riikliku õppekava loodusvaldkonna peaeesmärk. 
Artikli aluseks olev uuring on esimene, kus hinnati süstemaatiliselt gümnaasiumiõpilaste loodusteadusliku kirjaoskuse taset ja selle muutumist ópingute jooksul. Uurimisprobleemi lahendamise viis on uudne selle poolest, et loodusteadusliku kirjaoskuse tasemeid uuritakse longituudselt ja mitmedimensiooniliselt. Uurimistöös seati järgmised eesmärgid: töötada välja instrumendid gümnaasiumiõpilaste loodusteadusliku kirjaoskuse taseme hindamiseks ning hinnata nende abil õpilaste loodusteadusliku kirjaoskuse taset; kirjeldada longituuduuringuga loodusteadusliku kirjaoskuse kujunemise protsessi dünaamikat gümnaasiumiastme õpilaste näitel.

Artiklis vastatakse järgmistele uurimisküsimustele.

1. Milline on gümnaasiumi lõpuklasside õpilaste loodusteadusliku kirjaoskuse tase mõõdetuna probleemide lahendamise, otsuste tegemise ja põhjendamise oskuse, interdistsiplinaarsete teadmiste rakendamise oskuse, teaduse olemusest arusaamise ja oma oskustele hinnangu andmise kaudu?

2. Kuidas muutub õpilaste oskus seostada mõisteid ja moodustada nendest lauseid gümnaasiumiõpingute jooksul?

3. Kuidas muutub õpilaste loodusteadusliku kirjaoskuse tase gümnaasiumiõpingute jooksul?

\section{Teoreetiline ülevaade}

\section{Probleemid loodusteaduslikus hariduses}

Üks olulisimaid loodusteadusliku hariduse igikestvaid probleeme on teadmiste reprodutseerimise ületähtsustamine. Samas alatähtsustatakse oskust seostada loodusainete tundides kogutud teadmisi nii omavahel kui ka igapäevaeluga (Gilbert, 2006; Sadler \& Zeidler, 2005). Üha enam räägitakse vajadusest muuta loodusteaduslike õppeainete õpetamise filosoofilist kontseptsiooni nii, et haridus vastaks 21. sajandi nõuetele (Holbrook, 2008). Probleemiks on, et õpilased ei näe koolis õpitust kasu edaspidises elus, sest ettemääratud sisuga loodusteaduslikud óppeained, mis on üle koormatud faktide ja teooriatega, annavad vähe võimalusi divergentse mõtlemise arendamiseks (Hofstein, Eilks, \& Bybee, 2011; Sjöström, 2013). Seda kinnitavad põhikooli tasandil ka PISA 2015 uuringu tulemused. Selles uuringus jõudsid kõrgematele loodusteadusliku kirjaoskuse tasemetele (5. ja 6. tase) vaid vähesed Eesti õpilased. Nende tasemete ülesanded eeldavad näiteks oma valikute põhjendamist, keerukate nähtuste ja protsesside selgitamist, kasutades abstraktseid loodusteaduslikke mõisteid, samuti oskust seostada füüsika-, keemia-, bioloogia-, geograafia- ja astronoomiateadmisi 
omavahel, eristada teaduslikel tõenditel ja teooriatel põhinevaid ja mittepõhinevaid argumente ning rakendada õpitut õppekavavälises kontekstis (OECD, 2016).

Eelnimetatud oskused on olulised uue põlvkonna oskused (NGSS, 2013). Kui hindamise eesmärk on lasta õpilasel tunnis omandatut pelgalt reprodutseerida, jäävad paljud eluks vajalikud oskused kujundamata ning lõhe igapäevaelus vajalike ja koolis omandatud pädevuste vahel suureneb veelgi (Griffin et al., 2012; Partnership for 21st century skills, s. a.). Aastatel 2010-2014 Delphi meetodil tehtud rahvusvaheline küsitlus näitab, et ükski osalenud arvamusliidritest ei arva, et gümnaasiumilõpetajal peaksid olema vaid kõige madalamat loodusteadusliku kirjaoskuse taset iseloomustavad kompetentsid, mis seostuvad ainult kindla teadmiste kogumi omandamisega (Bolte et al., 2012; Laius, Post, \& Rannikmäe, 2016).

Kuna Eesti gümnaasiumites õpitakse loodusteaduslikke õppeaineid eraldi distsipliinidena ja sageli õpetavad neid ka erinevad õpetajad, siis hoolimata 2011. aastal vastu võetud kompetentsuspõhisest õppekavast (Gümnaasiumi riiklik õppekava, 2011), mis on loodusvaldkonna osas üles ehitatud rahvusvaheliselt aktsepteeritud kontseptsioonile „Haridus loodusteaduste kaudu“ (Holbrook \& Rannikmäe, 2007), ilmnevad üksikute õppeainete ainekavades endiselt erinevad rõhuasetused.

Soobardi ja Rannikmäe (2014) tehtud uuring näitab, et 10. klassi alguses väidab enamik õpilasi, et nad oskavad teha põhjendatud otsuseid (nõustus üle 50\%), kuid nad ei ole kindlad oma oskuses anda loodusteaduslikku selgitust ja lahendada loodusteaduslikke probleeme (nõustus alla 50\%). Samast uuringust selgus ka see, et õpilaste hinnangul kujundatakse nimetatud oskusi peamiselt bioloogia- ja geograafiatundides (nõustus üle 50\%). Keemiatundidega seoses nõustuvad õpilased, et neis kujundatakse oskust anda loodusteaduslikku selgitust, ent samas ei kujundata oskust lahendada loodusteadusliku sisuga laiemaid probleeme ja teha põhjendatud otsuseid. Füüsikatundide kohta väidavad õpilased, et neis kujundatakse oskust anda loodusteaduslikku selgitust ja lahendada loodusteadusliku sisuga probleeme, ent mitte oskust teha põhjendatud otsust (Soobard \& Rannikmäe, 2014).

\section{Loodusteaduslik kirjaoskus ja selle tasemelisuse mõõtmine}

Loodusteaduste õppimise peaeesmärk on loodusteadusliku kirjaoskuse kujundamine (Roberts, 2007). Roberts (2007) on selgitanud loodusteaduslikku kirjaoskust kahe visiooni - traditsioonilise ja progressiivse - kaudu. Esimesel juhul lähtutakse õpetamisel loodusteaduslikust sisust (I visioon), 
teisel juhul sisu rakendamisest igapäevaolukordades ja sotsiaalsetes kontekstides (II visioon). Seega on need kaks visiooni mingil määral äärmuslikud vastandid. Eeltoodud määratlusi kasutatakse ka rahvusvahelistes hindamisuuringutes, nagu PISA (pigem II visioon) ja TIMSS (I visioon). Eesti õppekava loodusvaldkonna seletuskiri ühtib Robertsi II visiooniga (Gümnaasiumi riiklik õppekava, 2011; Roberts, 2007).

Loodusteadusliku kirjaoskuse mõistet on tõlgendatud ja määratletud erinevalt, näiteks lähtudes õpiprotsessi tulemusest või rõhutades oskusi ja omadusi, mida õppija peab omandama (Laugksch, 2000). Leidub ka käsitlusi, kus keskendutakse õpetaja tegevustele ja õppemeetoditele, mille kaudu kujundatakse loodusteadusliku kirjaoskusega inimest (Van Eijck, 2012). Haridusfilosoofid rõhutavad loodusteadusliku kirjaoskuse erinevaid teaduse olemusega seotud ja sotsiaal-majanduslikke dimensioone, mis on aluseks hariduspoliitiliste otsuste tegemisele (McDonald, 2017; Roberts \& Bybee, 2014).

Siinses uurimuses defineeritakse loodusteaduslikku kirjaoskust Holbrooki ja Rannikmäe (2009) järgi kui oskust kasutada loodusteaduslikke teadmisi igapäeva- ja tööelus probleemide lahendamisel, otsuste tegemisel ja põhjendamisel, rõhutades seejuures väärtushinnangute olulisust. See määratlus on ka aluseks loodusvaldkonna pädevuste määratlemisele gümnaasiumi riiklikus õppekavas (2011). Loodusteadusliku kirjaoskuse hindamine peab olema seotud selliste oskuste ja situatsioonidega, mis motiveerivad õpilasi andma tähendusrikkaid vastuseid (Bennett, Lubben, \& Hogarth, 2007; Feinstein, 2010) ning tekitavad soovi oma teadmisi ja oskusi ka ise hinnata (Baartman \& Ruijs, 2011). Sellised igapäevasituatsioonid on komplekssed, hõlmates kõike alates rutiinsetest tegevustest ja lõpetades keerukate sotsiaal-teaduslike probleemide lahendamisega. See aga viitab, et loodusteaduslikust kirjaoskusest rääkides liigume kaugemale pelgalt kognitiivse õppimisega seotud ainesisu hindamisest. Senisest olulisemaks saab õpilaste oskus hinnata ise oma teadmisi ja oskusi, pidades siinjuures iseäranis silmas metakognitiivseid oskusi (Choi et al., 2011; Tytler, 2014).

Loodusteaduslik kirjaoskus ei ole ajas muutumatu kontseptsioon. Seda mõjutavad mitmed tegurid, nagu õpilaste vanus, omandatud teadmised ja oskused, suhtumine, hinnangud ja tegevused (sh õpetaja tegevused õppetöö läbiviimisel ja juhtimisel) nii koolis kui ka väljaspool kooli (sh ühiskondlik suhtlemine, sest õpilane on ühiskonna liige ja koolitund on osa sellest) (Bybee, 1993). Et loodusteadusliku kirjaoskuse muutusi paremini mõista, on Bybee (1993) defineerinud neli loodusteadusliku kirjaoskuse taset, mille kirjeldamisel lähtutakse üldisematest kategooriatest kui ainult hinnangu andmisest vahetult mõõdetavate aineteadmiste 
muutusele. Üksnes kognitiivseid õpitulemusi mõõtev ainealane test või küsimustik ei ole loodusteadusliku kirjaoskuse tasemete mõõtmiseks piisav. Hinnates loodusteaduslikku kirjaoskust, ei saa rääkida selle absoluutsest väärtusest (Bybee, 1997; Rannikmäe \& Soobard, 2014). Bybee (1997) nimetatud neljast tasemest on madalaimad nominaalse ja funktsionaalse kirjaoskuse tasemed. Need on võrreldavad nõudmistega rahuldava hinde saamiseks ja seega kirjeldavad nende õpilaste taset, kes on suutelised meenutama õpitut ja rakendama seda neile tuntud situatsioonides. Uuenduslikust ja loovast mõtlemisest jääb neil tasemetel puudu, ka on probleemiks suhtumine loodusainete õppimisse. Kõrgeimateks loodusteadusliku kirjaoskuse tasemeteks on strukturaalne ja mitmedimensiooniline tase, millest viimane on see, mille poole koolihariduses peaks püüdlema. Neid tasemeid iseloomustab oskus tulla kodanikuna eri situatsioonides toime, teha otsuseid ja neid põhjendada, uuenduslikult mõelda ja olla loov, kindlasti ka valmisolek teadusega seotud karjääriks (Rannikmäe \& Soobard, 2014). Õpilaste liikumine madalamatelt loodusteadusliku kirjaoskuse tasemetelt kõrgematele saab toimuda vaid siis, kui hindamisprotsess pakub neile võimalust oma mõtlemist ja metakognitiivseid oskusi arendada (Krjacik, 2011).

Loodusteadusliku kirjaoskuse tasemete hindamiseks on vaja välja töötada ja kasutada kompleksinstrumente, arvestades piiranguid, mis tulenevad nende kontseptuaalsest raamistikust. Sadler ja Zeidler (2009) rõhutavad sotsiaal-teaduslikele probleemidele ülesehitatud ülesannete olulisust progressiivse loodusteadusliku kirjaoskuse hindamisel. Sellised ülesanded on seotud mitte ainult induktiivsete, vaid ka deduktiivsete protsessidega. Näitena võib tuua instrumendi, millega hinnatakse kvantitatiivselt sotsiaalteadusliku põhjendamise oskust ning mis on üles ehitatud kahele õpilaste oskuste hindamise stsenaariumile (Romine et al., 2017).

\section{Teaduse olemuse koht loodusteaduslikus kirjaoskuses}

Kujundada õpilastes arusaama teadusest on üks teadushariduse, sh loodusteadusliku hariduse olulisi eesmärke. Arusaam teadusest moodustab ka osa loodusteadusliku kirjaoskuse vundamendist (Tytler, 2007). Teaduse olemuse uuringutes võib eristada kahte suunda: üks neist on teadusfilosoofiline, teine rõhuasetusega haridusele. Viimase puhul püütakse selgitada, missugused strateegiad ja praktikad on teaduse olemuse õpetamisel kõige efektiivsemad, st kas õpetada arusaama teadusest integreerituna nendesse õppeainetesse, kus teoreetiliste ja praktiliste tööde käigus selgitatakse erinevaid teaduse olemuse aspekte, või lahus teistest õppeainetest, eesmärgi- 
päraselt koostatud teadusprojektide raames. Mitmed uuringud näitavad viimati nimetatud praktika suuremat efektiivsust (Khishfe \& Lederman, 2007). Rannikmäe ja Rannikmäe (2014), tuginedes Afonso ja Gilberti (2010) töödele, näevad võimalust selgitada teaduse olemust ka Eesti koolis nn demarkatsiooni probleemi abil. Sellega seondub teaduse eristamine näiv- ehk pseudoteadusest. Kuna teadusuuringud on näidanud, et õpilastele üle maailma pakuvad huvi horoskoobid, ufod jt anomaalsed nähtused (Sjøberg \& Schreiner, 2002), siis oleks mõistlik kasutada seda ära nende huvi suurendamiseks loodusteaduslike õppeainete õppimise vastu ning kujundada ja hinnata selliste kontekstide abil ka nende arusaama teadusest.

Lederman, Abd-el-Khalick, Bell ja Schwartz (2002) leiavad, et mitte kõik teaduse olemusega seonduv ei ole õpilastele jõukohaselt mõistetav. Nii teadusfilosoofid kui ka haridusteadlased nõustuvad, et õpilased peaksid mõistma, et teadusel on empiiriline olemus, ja sellest tulenevalt eristama vaatlust ja järeldusi. Järeldustel on gnoseoloogiliselt eriline roll, kuna need on teaduse teoreetiliste konstruktide aluseks. Ei ole ühtset teaduslikku meetodit, kindlat tegevuste järjekorda, mis viiks õigete lahenduste ja vastusteni. Ka teaduse teooriad ja seadused on põhimõtteliselt erinevad: teooriad seletavad nähtusi, seadused aga kirjeldavad nende vahekorda. Eelöeldule lisaks on loodusteadusliku hariduse seisukohalt oluline, et õpilased mõistaksid ka teaduslike teadmiste muutuvust ajas ja sõltuvust teoreetilistest eeldustest ehk „teooriaga koormatust” (theory-laden). Kuna teaduslik teadmine sisaldab teadlaste loome- ja kujutlusvõimet, ei ole ka teadlaste loodud mudelid tegelikkuse koopiad.

Eelöeldu peaks jõudma õpilasteni loodusainete tundides, kus seisukohtade põhjendamisel ilmnevatele väärarusaamadele tuleks pöörata suurt tähelepanu (Rannikmäe \& Rannikmäe, 2014). Teaduse olemuse tutvustamine konkreetsete õppeainetega seotud teadmiste kontekstis loob aluse loodusteadusliku kirjaoskuse kujundamisele Robertsi (2007) I visiooni järgi. Seevastu komplekssed, teaduse rolli ja saavutusi ühiskonnas käsitlevad sotsiaal-teaduslikud probleemid loovad eelduse liikuda Robertsi (2007) mõistes progressiivse loodusteadusliku kirjaoskuse II visiooni tasandile.

Et hinnata teaduse olemuse mõistmist, on koostatud erinevaid mõõteinstrumente (nt Aikenhead \& Ryan, 1992; Chen, 2006). Enamik neist on valikvastustega vormis, sisaldades väiteid, mis iseloomustavad teadust ja teaduslikke teadmisi. Ka Eestis on neist mitmeid kasutatud, et võrrelda, kuidas õpilased ja õpetajad mõistavad arusaama teadusest (Rannikmäe, Rannikmäe, \& Holbrook, 2008). Rahvusvaheliselt on tuntud Wellingtoni (2000) koostatud küsimustik, mis võimaldab hinnata seisukohti skaaladel 
relativism-positivism, kontekstualism-dekontekstualism, instrumentalismrealism. Teadusliku teadmise tõesus on alati suhteline, relatiivne. Seevastu positivistid on veendunud, et teaduslikud teadmised on olulisemad kui mistahes muud teadmise vormid (Carnap, Hahn, \& Neurath, 1973). Teaduslik teadmine läheneb pidevalt absoluutsele tõele ja on võimeline seda lõppkokkuvõttes saavutama. Relativistide arvates sõltub teooria õigsus seda hindava sotsiaalse rühma normidest (Rannikmäe \& Rannikmäe, 2014). Eestis tehtud uurimistööd on näidanud, et loodusteaduslike õppeainete õpetajad kalduvad pigem positivistliku mõtlemise suunas (Wellington, 2000), kui tegemist on koolis õpetatava õppeainega. Seevastu õpilaste vaated on pigem relativistlikud ja seda mitte kooli õppeainega seoses, vaid teaduse kui ühiskondliku nähtuse tähenduses (Rannikmäe \& Rannikmäe, 2014).

\section{Mõistekaardi meetod}

Mõtestatud õppimise teooria järgi leiab õppimine aset vaid siis, kui uued teadmised seostatakse juba olemasolevatega, moodustades ühtse süsteemi (Ausubel, 1968). David Ausubeli mõtestatud õppimise teooria moodustab ka mõistekaardi meetodi teoreetilise aluse. Mõistekaart on informatsiooni esitamiseks mõeldud skemaatiline vahend, mille puhul on mõisted omavahel ühendatud seosesõnadega, moodustades mõistete struktuuri (Brinkerhoff \& Booth, 2013; Kinchin, 2014). Mõistetena võib käsitleda ja mõistekaardis kasutada ka näiteks seadusi või teooriaid. Mõistekaart luuakse tavaliselt kas ühe teema kohta või mingile konkreetsele fookusküsimusele (focus question) vastates (Novak \& Cañas, 2008). Siinses uurimuses esitatakse õpilastele fookusküsimus igapäevaeluga seotud stsenaariumi kohta.

Erinevad uuringud tõendavad, et mõistekaardi meetod arendab õpilaste kõrgemat järku mõtlemisoskust (Daley, 2004), aitab luua interdistsiplinaarseid seoseid erinevate valdkondade vahel, võimaldab kindlaks määrata väärarusaamu (Novak, 2010) ning saada kohest tagasisidet oma teadmiste kohta. Bramwell-Lalori ja Rainfordi (2013) uuring näitab, et mõistekaardi meetodi kasutamine klassiruumis suurendab õpilaste oskust luua seoseid varem omandatud teadmistega ja loob aluse teadmiste kasutamiseks probleemide lahendamisel. Kuna mõistekaardi meetodiga on võimalik saada olulist infot selle kohta, kuidas on õpitu salvestatud õpilase kognitiivsesse teadmiste struktuuri (Bramwell-Lalor \& Rainford, 2013), siis avardab see meetod võimalusi õpilaste teadmiste hindamiseks (Keppens \& Hay, 2008; Soika \& Reiska, 2013, 2014). 
Mõistekaartide kasutamisel hindamismeetodina on väga oluline tagada nende võrreldavus, sh tuleb luua võrdsed tingimused nii mõistekaartide koostamisel kui ka analüüsil (Ruiz-Primo, 2000; Reiska \& Soika, 2015). Mõistekaarte saab analüüsida nii kvalitatiivselt kui ka kvantitatiivselt. Mõistekaartide kvantitatiivne analüüs võimaldab hinnata mõistekaardi eri tunnuseid (Cañas, Novak, \& Reiska, 2015; Croasdell, Freeman, \& Urbaczewski, 2003; Keppens \& Hay 2008): mõistete arvu, seoste arvu, keerukuse astet, ristseoste arvu (crosslinks), hargnemiskohtade arvu, taksonoomia taset jne. Seejuures defineeritakse taksonoomia taset kui mõistekaardi struktuuri iseloomustavate tunnuste kombinatsiooni (Cañas et al., 2013). Praeguses töös kasutatakse hindamisel ka konstrueeritud lausete kvaliteeti.

Konstrueeritud lausete arv ja kvaliteet näitavad, kuidas oskab õpilane omavahel siduda eri mõisteid, moodustades nendest mõtestatud lausete struktuuri. Laused, mis on koostatud eri valdkonda kuuluvatest mõistetest, näitavad õpilase interdistsiplinaarseid teadmisi. Sõlmpunktide arv viitab õpilase oskusele siduda ühte mõistet eri mõistetega.

\section{Metoodika}

\section{Valim}

Uuringu tarbeks koostati representatiivne kihtvalim Eesti koolidest. Oluliste tunnustena arvestati regionaalsust ja kõigi 2010. aasta riigieksamite keskmist tulemust. EHISe andmetele toetudes moodustati populatsioon Eesti gümnaasiumiosaga üldhariduskoolidest (10.-12. klass). Selliseid koole oli Eestis 2010. aastal 226. Valimi moodustamisel jäeti välja vene õppekeelega koolid. Regionaalse arvulise tasakaalu saavutamiseks vaadeldi koole eraldi kolmes kihis: Tallinna koolid, suuremate linnade koolid ja väiksemates asulates paiknevad koolid. Selline jaotus vastab ka Eesti elanikkonna proportsionaalsele jaotusele. Gümnaasiumid igas kihis reastati kõigi riigieksamite keskmiste tulemuste alusel. Valimisse sattus reastusest iga neljas kool alates nimekirja esimesest koolist. Juhul kui kool mingil põhjusel (nt seoses haridusreformiga või osalemisega samal ajal mõnes teises suuremas uuringus) keeldus uuringus osalemast, võeti asemele sama rühma nimekirjas olevatest koolidest järgmine. Lõplik valim moodustus 42 koolist.

2011. aasta sügisel korraldati gümnaasiumiõpilaste loodusteadusliku kirjaoskuse uuring kõigis valimisse sattunud koolide 10. klassides (2216 õpilast), kus õpilased vastasid kõikidele komplekstesti osadele. 2013-2014. aastal testiti samade koolide õpilasi - siis olid õpilased juba 12. klassis (2010 õpilast). 


\section{Instrument}

Loodusteadusliku kirjaoskuse tasemeid mõõtva kompleksinstrumendi koostamisel lähtuti:

1) varasemate uuringute instrumentide disainist ja tulemustest, milles on määratud õpilaste loodusteadusliku kirjaoskuse tasemeid (OECD, 2007, 2016);

2) loodusteadusliku kirjaoskuse määratlustes välja toodud kompetentsustest, mida loodusteaduslikult kirjaoskajale inimesele omistatakse (Bybee, 1997; Choi et al., 2011; OECD, 2007; Holbrook \& Rannikmäe, 2009; Murcia, 2009);

3) Eesti üldhariduskooli riiklikus õppekavas gümnaasiumilõpetaja õpitulemustena nimetatud pädevustest, sest õpilaste teadmiste ja oskuste määramine peab olema kooskõlas õppekavaga (Gümnaasiumi riiklik õppekava, 2011);

4) õpilastele relevantsete kontekstide määratlusest (Gilbert, 2006; Gilbert, Bulte, \& Pilot, 2011);

5) teaduse olemuse mõistmise hindamisest ja seotusest kõrgemat järku kognitiivsete oskustega (Rannikmäe et al., 2008; McDonald, 2010).

Uuringu kompleksinstrument koosnes neljast osast. Esimeses, kognitiivses osas mõõdeti õpilaste loodusteadusliku kirjaoskuse tasemeid loodusteaduslike mõistete ja teooriate tundmise, interdistsiplinaarsete teadmiste kasutamise, probleemi lahendamise (sh uurimuslike oskuste) ning otsuse tegemise ja põhjendamise kaudu. Koostati neli interdistsiplinaarse sisuga reaalelulist probleemsituatsiooni (andmaks testile kontekstuaalsust), millest kahe kombinatsioonid moodustasid loodusteadusliku kirjaoskuse komplekstesti eri versioonide raamistiku. Probleemsituatsioonid esitati lühikeste õpilasi motiveerivate sotsiaal-teaduslike stsenaariumitena, mis seostusid ainekavade loodusteadusliku sisuga (nt jalavigastuse korral kasutatava külmakoti toimemehhanism, Surnumerest toodetavad mineraalid, laktoosi ensümaatiline lagundamine, keemistemperatuuri sõltuvus rõhust). Neile järgnesid sellega seotud ülesanded, millega hinnati loodusteadusliku kirjaoskuse tasemeid (Laius et al., 2016; Soobard \& Rannikmäe, 2015, vt lisa 1). Need kognitiivsete oskuste hindamise ülesanded koostati SOLO taksonoomia (The Structure of Observed Learning Outcomes) põhimõtteid järgides (Biggs \& Collis, 1982). SOLO tase I (üheplaanilisus) eeldab näiteks ópitu meenutamist, kordamist ja äratundmist, II tase (mitmetahulisus) kirjeldamist, kokkuvõtete tegemist ja järjestamist, III tase (seostatus) analüüsimist, võrdlemist, probleemide lahendamist, järeldamist ja rakendamist ning IV tase (üldistus) originaalset tõenduskäiku, millegi koostamist, 
loomist, väljatöötamist ja tõestamist. Koostatud kognitiivse testi osa valiidsus (construct validity) tagati eksperdimeetodil, kasutades nelja sõltumatut loodusainete õpetajast eksperti ja nelja rahvusvaheliselt tuntud haridusteadlast.

Kompleksinstrumendi teise osaga hinnati teaduse olemuse mõistmist, mis seostus oskusega eristada pseudoteadust teadusest ning põhjendada oma nõustumist teaduslike teadmiste muutuvusega ajas, teooriate ja seaduste eristamise võimalustega ning teadustöö meetoditega.

Kolmandas osas küsiti õpilastelt hinnangut oma oskustele, mis seostusid loodusteadusliku kirjaoskuse määratluses nimetatud komponentidega (Holbrook \& Rannikmäe, 2009).

Mõistekaardi koostamine moodustas neljanda osa ja oli vahetult seotud testi esimeses osas kasutatud stsenaariumitega. Õpilastele esitati stsenaariumiga seotud 30 mõistet, mis seostusid kas loodusteadusliku protsessi või igapäevaelulise rakendusega. Õpilastele esitatud mõisted valiti välja nii, et neid oleks kõigist neljast loodusainest (bioloogia, füüsika, geograafia ja keemia).

Kompleksinstrumenti tervikuna katsetati koolides, mis valimisse ei kuulunud. Reliaablus arvutati Cronbachi alfa abil: instrumendi esimeses osas oli see 0,85 , teises 0,82 ja kolmandas 0,93 . Kolmele esimesele testi osale vastamine võttis aega 90 minutit. Mõistekaart koostati kolmele esimesele osale järgneva kahe nädala jooksul arvutiklassis ja selleks kulus 45 minutit. Longituuduuringu teises etapis (12. klassis) anti igale õpilasele vastamiseks üks stsenaarium 10. klassis vastatust, teine stsenaarium muutus.

\section{Andmeanalüïs}

Kõigi uuringus osalenud õpilaste vastuseid kasutati 10. ja 12. klassi tulemuste võrdlemisel loodusteadusliku kirjaoskuse tasemete testi üksikosades. Selleks jagati valim nelja võrreldava õpilaste arvuga gruppi, lähtudes koolide 2010. aasta riigieksamite keskmistest tulemustest (kahanevas järjekorras): grupp I - 1003 õpilast 8 koolist, grupp II - 1034 õpilast 8 koolist, grupp III - 976 õpilast 12 koolist, grupp IV - 1025 õpilast 16 koolist.

Kui õpilaste loodusteadusliku kirjaoskuse tasemete hindamisel kasutati kõigi uuringus osalenud õpilaste vastuseid, siis 10. ja 12. klassi õpilaste loodusteadusliku kirjaoskuse taseme muutuse kirjeldamiseks kasutati vaid nende õpilaste vastuseid, kes olid vastanud nii 10. kui ka 12. klassis. Selliseid õpilasi oli 1335. Valiidsuse tagamiseks võrreldi õpilaste vastuste sagedusjaotusi nende õpilaste omadega, kes osalesid ainult kas esimesel või viimasel testimisel. 
Kompleksinstrumendi esimeses (kognitiivses) osas analüüsiti õpilaste vastuseid kolmepallisel skaalal. Testi tulemuste kodeerimisel kasutati kahte eksperti, nendevahelise kodeerimise kooskõla oli 98\%. Teises osas (teaduse olemus) väljendasid õpilased nõustumist väidetega skaalal nõustun - ei nõustu ning seejärel põhjendasid nad oma vastuseid. Põhjendused kategoriseeriti järgmiselt: teaduslikult korrektsed, igapäevaeluga seotud ning väärarusaamadega vastused. Kategooriad valideeris neli eksperti etteantud kategooriate kirjelduste alusel. Kokkulangevus oli 85\%. Kolmandas osas (hinnangud oskustele) hindasid õpilased loodusteadusliku kirjaoskuse komponentidega seotud oskusi neljapallisel skaalal. Õpilaste vastuste kirjeldamiseks kasutati aritmeetilist keskmist ja standardhälvet.

Mõistekaarte koguti 2011. aastal 1606 (10. klass) ja 2014. aastal 996 (12. klass), 784 õpilast tegid samal teemal mõistekaardid mõlemas klassis. Mõistekaarte teinud õpilaste kognitiivse testi tulemused ei erinenud oluliselt mõistekaarte mitteteinud õpilaste testide tulemustest $(p=0,44)$.

Andmeid analüüsiti statistikaprogrammiga IBM SPSS Statistic 23. Andmete võrdlemiseks kasutati kirjeldavaid statistikuid, Pearsoni ja Spearmanni korrelatsioonanalüüse, $t$-testi ja ühesuunalist ANOVA testi. Lisaks arvutati kõigil juhtudel standardhälbe põhjal mõju suurus (effect size) (Cohen, 1988). Mõistekaartide hindamiseks arendati välja programm Cmap-Analysis, mille abil määrati loodud seoste arv, mõistete tsentraalsus, hargnemiskohtade arv, seoste arv mõiste kohta, mõistekaartide taksonoomia tase jt kvantitatiivsed tunnused (Cañas, Bunch, Novak, \& Reiska, 2013).

\section{Tulemused}

Õpilaste vastuseid analüüsiti 2010. aastal gümnaasiumi lõpetanud õpilaste keskmiste eksamitulemuste järgi moodustatud kooligruppide kaupa. Et anda sisukam ülevaade õpilaste vastustest, on tulemused esitatud vastavalt sagedusjaotustele, sest loodusteadusliku kirjaoskuse tasemete kirjeldamisel on oluline nii õigete vastuste kui ka väärarusaamasid sisaldavate vastuste osakaal. Tabel 1 näitab, et nii 10. kui ka 12. klassi õpilaste kognitiivse testi tulemused on parimad õppekavaga seotud aineteadmiste reprodutseerimisel. Need oskused on ainespetsiifilised, olles paremad keemia ja füüsika õppeaine sisuga seotud ülesannetes kõigi võrreldavate kooligruppide õpilaste puhul. Silma torkab ka osaliselt õigete või väärarusaamu sisaldavate vastuste suurem osakaal bioloogia ja geograafia õppeainete sisuga seotud ülesannetes. Õpilaste oskus reprodutseerida aineteadmisi muutub gümnaasiumi jooksul peamiselt valede vastuste vähenemise ja osaliselt õigete 
vastuste suurenemise tulemusena. 5-7\% piires kasvab õigete vastuste osakaal halvemate eksamitulemustega kooligruppide õpilastel.

Interdistsiplinaarsete teadmiste rakendamisel on 12. klassi õpilaste tulemused 10. klassi õpilaste omadest küll paremad, kuid sellegipoolest ei saa õigete vastuste arvu kasvu 5-10\% piires suhteliselt madala algtaseme korral vaadata kui teadmiste ja oskuste omandamise märkimisväärset paranemist - osaliselt õigete ja väärarusaamadega vastuste osakaal on liiga suur. Seega olulist kvalitatiivset hüpet 12. klassi õpilaste interdistsiplinaarsete teadmiste rakendamise oskuste korral ei täheldatud, kuigi seda võiks eeldada õppekavaga määratud sisuteadmiste juurdekasvu arvestades. Kõigil juhtudel arvutati ka mõju suurus, mis oli tunduvalt väiksem kui 0,2 ning ei olnud statistiliselt oluline.

Loodusteadusliku sisuga probleemide lahendamisel jäävad hätta nii eksamitulemuste järgi esimesse (parimate tulemustega) rühma kuuluvate koolide õpilased kui ka halvimate eksamitulemustega koolide õpilased. Murettekitav on asjaolu, et üle $80 \%$ õpilastest ei oska probleeme lahendada ja see oskus ei arene kolme gümnaasiumiaasta jooksul.

Ka otsuste tegemise ja põhjendamise oskus gümnaasiumi jooksul peaaegu ei muutu. Siiski on see oskus paremini omandatud kui probleemide lahendamise oskus ja seda tänu otsuste osaliselt õigete (ühel argumendil põhinevate) põhjendustele. Needki muutused on toimunud üksikõpilase tasandil ja valimi kui terviku piires ei ole need olulised (mõju suurus alla $0,2)$.

Lisa 2 tabelis on toodud ANOVA väärtused, mis on arvutatud loodusteadusliku kirjaoskuse tasemete kognitiivse testi ülesannetega mõõdetud oskuste keskmiste tulemuste alusel ja mis võimaldavad otsustada erinevuste üle. Enim erinevusi on parimate eksamitulemustega grupi ja teiste gruppide koolide õpilaste tulemuste vahel. Vahepealsete eksamitulemustega (II ja III) gruppidesse kuuluvate koolide õpilaste vastused omavahel oluliselt ei erine. Üldtendents näitab, et erinevused vähenevad 12. klassi õpilaste vahel kõigi oskuste korral. Eri eksamigruppidesse kuuluvate koolide õpilaste vahel ei ole teadusliku sisuga probleemide lahendamise oskustes ja otsuse tegemise oskustes mingeid erinevusi. Ainespetsiifiliste teadmiste reprodutseerimises on erinevusi keemiaga seotud teadmiste reprodutseerimise korral. 
Tabel 1. 10. ja 12. klassi õpilaste kognitiivsete oskuste võrdlus

\begin{tabular}{|c|c|c|c|c|c|c|c|c|c|c|c|c|c|c|}
\hline \multirow{3}{*}{\multicolumn{2}{|c|}{$\begin{array}{l}\text { Oskused (näited LKT } \\
\text { kognitiivsest osast koos } \\
\text { ülesandele vastanud õpilaste } \\
\text { arvuga) }\end{array}$}} & \multirow{4}{*}{\begin{tabular}{c|} 
Klass \\
\\
10
\end{tabular}} & \multicolumn{12}{|c|}{ Eksamigrupid (testis osalenud õpilaste arv 10. ja 12. klassis) } \\
\hline & & & \multicolumn{3}{|c|}{$\begin{array}{c}\text { I } \\
N_{10}=656 \\
N_{12}=347\end{array}$} & \multicolumn{3}{|c|}{$\begin{array}{c}\| \\
N_{10}=548 \\
N_{12}=486\end{array}$} & \multicolumn{3}{|c|}{$\begin{array}{c}\text { III } \\
N_{10}=481 \\
N_{12}=495\end{array}$} & \multicolumn{3}{|c|}{$\begin{array}{c}\text { IV } \\
N_{10}=531 \\
N_{12}=494\end{array}$} \\
\hline & & & $\begin{array}{c}0 \\
(\%)\end{array}$ & $\begin{array}{c}1 \\
(\%)\end{array}$ & $\begin{array}{c}2 \\
(\%)\end{array}$ & $\begin{array}{c}0 \\
(\%)\end{array}$ & $\begin{array}{c}1 \\
(\%)\end{array}$ & $\begin{array}{c}2 \\
(\%)\end{array}$ & $\begin{array}{c}0 \\
(\%)\end{array}$ & $\begin{array}{c}1 \\
(\%)\end{array}$ & $\begin{array}{c}2 \\
(\%)\end{array}$ & $\begin{array}{c}0 \\
(\%)\end{array}$ & $\begin{array}{c}1 \\
(\%)\end{array}$ & $\begin{array}{c}2 \\
(\%)\end{array}$ \\
\hline \multirow{4}{*}{$\begin{array}{l}\text { Loodus- } \\
\text { teadusliku } \\
\text { sisuga prob- } \\
\text { leemide } \\
\text { lahenda- } \\
\text { mine } \\
\text { (SOLO III) }\end{array}$} & \multirow{2}{*}{$\begin{array}{c}\text { Probleem } 1 \\
N_{10}=1116 \\
N_{12}=932\end{array}$} & & 83 & 15 & 2 & 92 & 7 & 1 & 84 & 14 & 2 & 88 & 10 & 2 \\
\hline & & 12 & 76 & 17 & 7 & 82 & 17 & 1 & 81 & 18 & 1 & 79 & 20 & 1 \\
\hline & \multirow{2}{*}{$\begin{array}{c}\text { Probleem } 2 \\
N_{10}=1083 \\
N_{12}=953\end{array}$} & 10 & 72 & 12 & 16 & 83 & 9 & 8 & 80 & 13 & 7 & 86 & 8 & 6 \\
\hline & & 12 & 70 & 14 & 15 & 79 & 11 & 10 & 80 & 9 & 11 & 77 & 9 & 14 \\
\hline \multirow{4}{*}{$\begin{array}{l}\text { Otsuse } \\
\text { tegemine } \\
\text { koos põh- } \\
\text { jendusega } \\
\text { (SOLO IV) }\end{array}$} & \multirow{2}{*}{$\begin{array}{c}\text { Otsus } 1 \\
N_{10}=1116 \\
N_{12}=932\end{array}$} & 10 & 60 & 33 & 7 & 76 & 21 & 3 & 66 & 29 & 5 & 78 & 19 & 3 \\
\hline & & 12 & 40 & 43 & 17 & 52 & 40 & 8 & 54 & 36 & 10 & 50 & 44 & 6 \\
\hline & \multirow{2}{*}{$\begin{array}{c}\text { Otsus } 2 \\
N_{10}=1128 \\
N_{12}=946\end{array}$} & 10 & 46 & 45 & 9 & 57 & 38 & 5 & 57 & 38 & 5 & 58 & 38 & 4 \\
\hline & & 12 & 53 & 35 & 12 & 55 & 35 & 10 & 58 & 31 & 11 & 48 & 40 & 12 \\
\hline \multirow{4}{*}{$\begin{array}{l}\text { Inter- } \\
\text { distsipli- } \\
\text { naarsete } \\
\text { teadmiste } \\
\text { rakenda- } \\
\text { mine } \\
\text { (SOLO II) }\end{array}$} & \multirow{2}{*}{$\begin{array}{c}\text { Rakendamine } 2 \\
N_{10}=1083 \\
N_{12}=953\end{array}$} & 10 & 16 & 59 & 25 & 62 & 11 & 27 & 65 & 12 & 23 & 57 & 16 & 27 \\
\hline & & 12 & 57 & 8 & 35 & 59 & 11 & 30 & 58 & 14 & 28 & 63 & 12 & 25 \\
\hline & \multirow{2}{*}{$\begin{array}{c}\text { Rakendamine } 3 \\
N_{10}=1128 \\
N_{12}=946\end{array}$} & 10 & 6 & 62 & 32 & 15 & 52 & 13 & 12 & 69 & 19 & 16 & 53 & 31 \\
\hline & & 12 & 27 & 34 & 40 & 39 & 36 & 25 & 35 & 39 & 26 & 37 & 32 & 31 \\
\hline \multirow{8}{*}{$\begin{array}{l}\text { Aine- } \\
\text { teadmiste } \\
\text { reprodut- } \\
\text { seerimine } \\
\text { (SOLO I) }\end{array}$} & \multirow{2}{*}{$\begin{array}{c}\text { Teadmised B } \\
N_{10}=1116 \\
N_{12}=932\end{array}$} & 10 & 20 & 26 & 54 & 24 & 26 & 50 & 21 & 32 & 47 & 22 & 30 & 48 \\
\hline & & 12 & 27 & 19 & 54 & 31 & 25 & 44 & 33 & 24 & 43 & 34 & 26 & 40 \\
\hline & \multirow{2}{*}{$\begin{array}{c}\text { Teadmised G } \\
N_{10}=1128 \\
N_{12}=946\end{array}$} & 10 & 3 & 54 & 43 & 2 & 68 & 30 & 13 & 57 & 30 & 4 & 62 & 34 \\
\hline & & 12 & 1 & 44 & 55 & 4 & 55 & 41 & 2 & 56 & 42 & 2 & 53 & 45 \\
\hline & \multirow{2}{*}{$\begin{array}{c}\text { Teadmised K } \\
N_{10}=1083 \\
N_{12}=953\end{array}$} & 10 & 34 & 4 & 62 & 49 & 4 & 47 & 56 & 5 & 39 & 51 & 4 & 45 \\
\hline & & 12 & 14 & 21 & 65 & 20 & 29 & 51 & 24 & 25 & 51 & 29 & 25 & 46 \\
\hline & \multirow{2}{*}{$\begin{array}{c}\text { Teadmised F } \\
N_{10}=1094 \\
N_{12}=938\end{array}$} & 10 & 28 & 0 & 72 & 39 & 0 & 61 & 40 & 0 & 60 & 40 & 0 & 60 \\
\hline & & 12 & 26 & 0 & 74 & 35 & 0 & 65 & 42 & 0 & 58 & 32 & 0 & 68 \\
\hline
\end{tabular}

Märkused. 0 - vale vastus, 1 - osaliselt õige, sh väärarusaamu sisaldav vastus, 2 - teaduslikult korrektne vastus. Ainekavapõhised teadmised: B - bioloogia, K - keemia, G - geograafia, F füüsika.

Tabel 2 näitab, et õpilaste arusaamad teadusest on positivistliku suundumusega, seejuures ei ilmne Spearmanni koefitsiendi järgi arvutatuna korrelatiivseid seoseid erinevate teaduse olemuse aspektidega nõustumise ja põhjendamise tüübi vahel (Spearmanni koefitsiendi väärtused jäid 10. klassis 
vahemikku $0,02-0,28$ ja 12 . klassis $0,08-0,26$ ). Õpilaste vastused on juhusliku iseloomuga, isegi teaduslikult korrektselt põhjendatud seisukohad ei ole gümnaasiumi vältel püsivad. Positivistlike arusaamadega põhjenduste üldarv küll väheneb gümnaasiumi jooksul, kuid nende õpilaste osakaal, kes annavad mõne aspektiga seoses positivistliku põhjenduse, muutub vähe. Lisaks ilmneb tabelist 2, et pseudoteaduslike seisukohtadega nõustumise määr on küllaltki kõrge. See küll väheneb ühe konkreetse väite piires, kui õpilased jõuavad 10. klassist 12. klassi, kuid üle seitsme väite põhjal arvutatud keskmine nõustumise arv jääb peaaegu muutumatuks. Ka statistilist erinevust eksamitulemuste põhjal moodustatud kooligruppidesse kuuluvate õpilaste vastuste vahel ei leitud.

Tabel 2. Teaduse olemuse mõistmine (\%)

\begin{tabular}{|c|c|c|c|c|c|c|c|c|}
\hline \multirow{3}{*}{$\begin{array}{l}\text { Näited teadusest } \\
\text { arusaamise } \\
\text { aspektidega } \\
\text { nõustumise ja } \\
\text { põhjendamise kohta }\end{array}$} & \multicolumn{8}{|c|}{ Eksamigrupid } \\
\hline & \multicolumn{2}{|c|}{$N=1003$} & \multicolumn{2}{|c|}{$N=1034$} & \multicolumn{2}{|c|}{$\begin{array}{c}\text { III } \\
N=976\end{array}$} & \multicolumn{2}{|c|}{$\begin{array}{c}\text { IV } \\
N=1025\end{array}$} \\
\hline & $\begin{array}{c}10 \\
N=656\end{array}$ & $\begin{array}{c}12 \\
N=347\end{array}$ & $\begin{array}{c}10 \\
N=548\end{array}$ & $\begin{array}{c}12 \\
N=486\end{array}$ & $\begin{array}{c}10 \\
N=481\end{array}$ & $\begin{array}{c}12 \\
N=495\end{array}$ & $\begin{array}{c}10 \\
N=531\end{array}$ & $\begin{array}{c}12 \\
N=494\end{array}$ \\
\hline
\end{tabular}

Teaduslike teadmiste absoluutne tõesus

\begin{tabular}{r|c|c|c|c|c|c|c|c}
\hline Positivism & 73,6 & 52,1 & 74,1 & 61,5 & 70,9 & 59,2 & 71,2 & 62,8 \\
\hline Relativism & 26,2 & 47,9 & 25,9 & 38,5 & 29,1 & 40,8 & 28,8 & 37,2 \\
\hline
\end{tabular}

Mudelite ja teooriate loomine

\begin{tabular}{|c|c|c|c|c|c|c|c|c|}
\hline Positivism & 56,2 & 35,4 & 54,7 & 30,7 & 56,5 & 36,7 & 54,8 & 35,2 \\
\hline Relativism & 43,8 & 64,6 & 45,3 & 69,3 & 43,5 & 63,3 & 45,2 & 64,8 \\
\hline \multicolumn{9}{|l|}{ Teadus kui osa kultuurist } \\
\hline Positivism & 81,2 & 65,7 & 87,6 & 65,8 & 84,2 & 69,4 & 87,4 & 64,6 \\
\hline Relativism & 18,8 & 34,3 & 12,4 & 34,2 & 15,8 & 30,6 & 12,6 & 35,4 \\
\hline $\begin{array}{l}\text { Neljast põhjendusest } \\
\text { min üks positivistlik }\end{array}$ & 89,1 & 86,2 & 92,3 & 89,2 & 89,3 & 86,2 & 93,4 & 91,2 \\
\hline $\begin{array}{r}\text { Pseudoteaduslike } \\
\text { väidetega nõustumine } \\
(\max =7), \bar{x}(S D)\end{array}$ & $\begin{array}{c}2,5 \\
(1,3)\end{array}$ & $\begin{array}{c}2,5 \\
(1,2)\end{array}$ & $\begin{array}{c}2,4 \\
(1,4)\end{array}$ & $\begin{array}{c}2,4 \\
(1,2)\end{array}$ & $\begin{array}{c}2,5 \\
(1,5)\end{array}$ & $\begin{array}{l}2,5 \\
(1,3)\end{array}$ & $\begin{array}{c}2,4 \\
(1,4)\end{array}$ & $\begin{array}{c}2,6 \\
(1,2)\end{array}$ \\
\hline \multicolumn{9}{|c|}{ Planeedid mõjutavad keskkonda ja käitumist } \\
\hline Nõustun & 41,9 & 34,7 & 49,0 & 40,3 & 50,0 & 43,6 & 50,1 & 49,3 \\
\hline Ei nõustu & 58,1 & 65,3 & 51,0 & 59,7 & 50,0 & 56,4 & 49,9 & 50,7 \\
\hline \multicolumn{9}{|c|}{ Horoskoobid on kui hüpoteesid } \\
\hline Nõustun & 41,2 & 25,0 & 34,6 & 25,5 & 37,8 & 29,5 & 36,1 & 28,4 \\
\hline Ei nõustu & 58,2 & 75,0 & 65,4 & 74,5 & 62,2 & 70,5 & 63,9 & 71,6 \\
\hline
\end{tabular}


Õpilaste hinnangud oma oskustele (tabel 3) on eksamigruppide ja klasside võrdluses sarnased. Sõltumata eksamigrupist ja klassist annavad õpilased kõrgeid hinnanguid interdistsiplinaarsete teadmiste rakendamisele ja otsuse tegemisele koos põhjendusega. Mõnevõrra madalamalt hindavad ópilased oma oskust lahendada loodusteadusliku sisuga probleeme ning demonstreerida seejuures uurimuslikke oskusi. Statistiliselt olulised erinevused eksamigruppide vahel on ainult interdistsiplinaarsete teadmiste kasutamises.

Tabel 3. Õpilaste hinnangud oma oskustele $(\max =4)$

\begin{tabular}{|c|c|c|c|c|c|c|c|c|c|}
\hline \multirow{3}{*}{\multicolumn{2}{|c|}{ Oskused }} & \multicolumn{8}{|c|}{ Eksamigrupid } \\
\hline & & \multicolumn{2}{|c|}{1} & \multicolumn{2}{|c|}{ ॥ } & \multicolumn{2}{|c|}{ III } & \multicolumn{2}{|c|}{ IV } \\
\hline & & $\begin{array}{c}10 . \mathrm{kl} \\
N=656\end{array}$ & $\begin{array}{c}12 . \mathrm{kl} \\
N=347\end{array}$ & $\begin{array}{c}10 . \mathrm{kl} \\
N=548\end{array}$ & $\begin{array}{c}12 . \mathrm{kl} \\
N=486\end{array}$ & $\begin{array}{c}\text { 10. kl } \\
N=481\end{array}$ & $\begin{array}{c}12 . \mathrm{kl} \\
N=495\end{array}$ & $\begin{array}{c}\begin{array}{c}10 . \mathrm{kl} \\
N=531\end{array}\end{array}$ & $\begin{array}{c}\begin{array}{c}12 . \mathrm{kl} \\
N=494\end{array}\end{array}$ \\
\hline $\begin{array}{l}\text { Loodusteadusliku } \\
\text { sisuga } \\
\text { probleemide } \\
\text { lahendamine }\end{array}$ & $\begin{array}{c}\bar{x} \\
(S D)\end{array}$ & $\begin{array}{c}2,39 \\
(0,72)\end{array}$ & $\begin{array}{c}2,41 \\
(0,75)\end{array}$ & $\begin{array}{c}2,27 \\
(0,71)\end{array}$ & $\begin{array}{c}2,32 \\
(0,72)\end{array}$ & $\begin{array}{c}2,30 \\
(0,70)\end{array}$ & $\begin{array}{c}2,17 \\
(0,72)\end{array}$ & $\begin{array}{c}2,30 \\
(0,70)\end{array}$ & $\begin{array}{c}2,29 \\
(0,72)\end{array}$ \\
\hline $\begin{array}{l}\text { Otsuse } \\
\text { tegemine koos } \\
\text { põhjendusega }\end{array}$ & $\begin{array}{c}\bar{x} \\
(S D)\end{array}$ & $\begin{array}{c}2,74 \\
(0,85)\end{array}$ & $\begin{array}{c}2,70 \\
(0,83)\end{array}$ & $\begin{array}{c}2,67 \\
(0,81)\end{array}$ & $\begin{array}{c}2,65 \\
(0,82)\end{array}$ & $\begin{array}{c}2,72 \\
(0,84)\end{array}$ & $\begin{array}{c}2,59 \\
(0,86)\end{array}$ & $\begin{array}{c}2,57 \\
(0,84)\end{array}$ & $\begin{array}{c}2,65 \\
(0,87)\end{array}$ \\
\hline $\begin{array}{l}\text { Interdistsipli- } \\
\text { naarsete } \\
\text { teadmiste } \\
\text { kasutamine }\end{array}$ & $\begin{array}{c}\bar{x} \\
(S D)\end{array}$ & $\begin{array}{c}2,61 \\
(0,75)\end{array}$ & $\begin{array}{c}2,61 \\
(0,76)\end{array}$ & $\begin{array}{c}2,54 \\
(0,74)\end{array}$ & $\begin{array}{c}2,49 \\
(0,73)\end{array}$ & $\begin{array}{c}2,59 \\
(0,72)\end{array}$ & $\begin{array}{c}2,42 \\
(0,76)\end{array}$ & $\begin{array}{c}2,55 \\
(0,75)\end{array}$ & $\begin{array}{c}2,47 \\
(0,75)\end{array}$ \\
\hline
\end{tabular}

10. ja 12. klassi õpilaste koostatud mõistekaartide analüüsimisel lähtuti konstrueeritud lausete arvust, mõistekaartide tihedusest (seoste arv mõiste kohta), lausete kvaliteedist, sõlmpunktide arvust ja struktuurist. Samuti analüüsiti mõistekaardi taksonoomia taset, mis kirjeldab erinevaid struktuuritunnuseid. Tulemustest ilmneb, et 12. klassi õpilased konstrueerivad mõnevõrra enam lauseid, nende mõistekaardid sisaldavad rohkem sõlmpunkte ja nad saavutavad mõnevõrra kõrgema taksonoomia taseme kui 10. klassi õpilased (tabel 4 ja joonis 1). Samas on keskmised tulemused ka 12. klassis maksimaalsete väärtustega võrreldes suhteliselt tagasihoidlikud. Näiteks on taksonoomia maksimaalne tase 6 . Tabelis 4 esitatud keskmiste võrdlused $t$-testiga näitavad, et kõik erinevused on statistiliselt olulised. 
Tabel 4. 10. ja 12. klassi õpilaste koostatud mõistekaartide võrdlus

\begin{tabular}{l|c|c|c|c|c|c}
\hline Tunnus & Klass & $N$ & $\bar{x}$ & $S D$ & $t$ & Sig. \\
\hline $\begin{array}{l}\text { Lausete arv } \\
\text { Max = 40 }\end{array}$ & 10 & 784 & 20,49 & 8,40 & $-7,192$ & 0,000 \\
\cline { 2 - 7 } & 12 & 784 & 23,55 & 8,45 & $-7,192$ & 0,000 \\
\hline $\begin{array}{l}\text { Sõlmpunktide arv } \\
\text { Max = 15 }\end{array}$ & 10 & 784 & 4,21 & 2,71 & $-6,568$ & 0,000 \\
\cline { 2 - 7 } & 12 & 784 & 5,13 & 2,82 & $-6,568$ & 0,000 \\
\hline $\begin{array}{l}\text { Taksonoomia tase } \\
\text { Max =6 }\end{array}$ & 10 & 784 & 2,51 & 1,42 & $-4,287$ & 0,000 \\
\cline { 2 - 7 } & 12 & 784 & 2,84 & 1,63 & $-4,287$ & 0,000 \\
\hline
\end{tabular}

Joonisel 1 on esitatud 10. ja 12. klassi õpilaste moodustatud lausete arv mõistekaartides. Jooniselt on näha, et 12. klassi õpilased on moodustanud oma mõistekaartides mõnevõrra enam lauseid kui 10. klassi õpilased. Seda illustreerib ka polünoomne trendijoon, mille maksimum on 12. klassi puhul paremal pool kui 10. klassil.

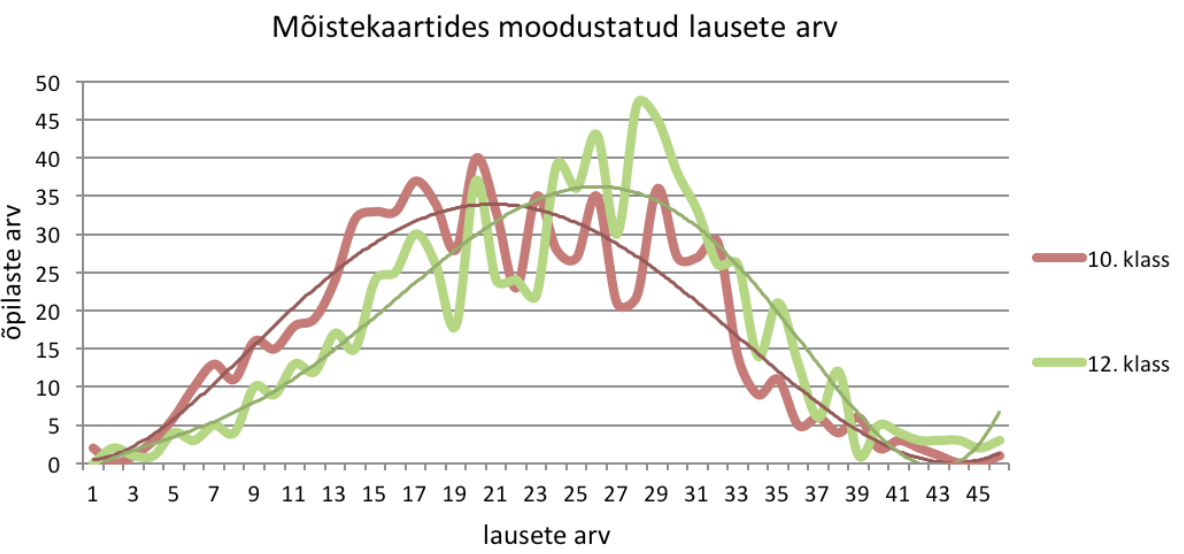

Joonis 1. Konstrueeritud lausete arv 10. ja 12. klassi õpilaste $(N=784)$ mõistekaartides

Erinevate mõistekaartide tunnuste ja loodusteadusliku kirjaoskuse testide tulemuste vaheliste seoste väljaselgitamiseks tehti 10. klassi andmete põhjal korrelatsioonanalüüs (arvutati Pearsoni korrelatsioon), mis näitas, et korrelatsioonid on statistiliselt olulised. Kõige tugevamalt korreleerub testi tulemustega mõistekaardi tunnus, mis on seotud loodud lausete kvaliteediga, ehk see, kuidas õpilased saavad aru analüüsitavast probleemist $(r=$ $0,32, p<0,001)$. Samuti olid statistiliselt olulised korrelatsioonid ka mitmete teiste mõistekaardi tunnuste ja testi tulemuste vahel: lausete koguarv ( $r=$ $0,24, p<0,001)$, hargnemiskohtade arv $(r=0,27, p<0,001)$ ja seoste arv 
mõiste kohta $(r=0,25, p<0,001)$. Sellest tuleneb, et õpilased, kellel olid eelkirjeldatud tunnuste väärtused suuremad, on ka kõrgemal loodusteadusliku kirjaoskuse tasemel.

Lisas 3 on esitatud kaks näidet mõistekaartide kohta. Mõistekaardid on valitud eri taksonoomia tasemetelt (Cañas et al., 2013). Esimene mõistekaart asetseb taksonoomia tasandil 0 . Selles mõistekaardis on vaid vähesed mõisted omavahel seotud, puuduvad seosesõnad, hierarhia tasandeid on vaid üks, hargnemiskohti on vähe ja puuduvad ristseosed. Teine mõistekaart on taksonoomia tasandil 6, mis tähendab, et enamik mõistetest on omavahel seotud, hierarhia tasandeid on vähemalt kolm ja hargnemiskohtade arv on suurem kui seitse, samuti esineb mõistekaardis enam kui kaks ristseost.

Loodusteadusliku kirjaoskuse taseme määramisel võeti arvesse nii kognitiivse testi kui ka teaduse olemusest arusaamise tulemusi. Kognitiivse testi loodusteadusliku sisu analüüsimisel standardiseeriti testi osa (kahel kontekstipõhisel stsenaariumil põhinevate ülesannete kombinatsioonide) ülesannete punktisummad. Loodusteadusliku kirjaoskuse tasemete määramisel võeti aluseks normaaljaotus. Samal tasemel olevate õpilaste kognitiivse testi punktisumma erines II ja III tasemel standardhälbe võrra vastavast keskmisest. Loodusteadusliku kirjaoskuse I ja IV tasemel olevate õpilaste punktisummad erinesid kuni kahekordse standardhälbe ulatuses. Kognitiivses testis saavutasid ópilased 10. klassis alla 45\% maksimaalselt võimalikest punktidest, 12 . klassis oli see 5\% võrra kõrgem, kuid statistiliselt mitteoluline, arvestades mõju (effect size) suurust (alla 0,2). Samal meetodil leiti tasemed ka teaduse olemuse mõistmist hindavas osas.

Tabel 5 illustreerib õpilaste liikumist gümnaasiumis loodusteadusliku kirjaoskuse tasemete vahel. Muutused on üksikõpilaste tasandil, kuid statistiliselt mitteolulised, arvestades mõju suurust (alla 0,2 ) ja seda, et tasemetevaheline erinevus on $10 \%$ piires üldisest saavutatud punktisummast. Tasemel 4 on 182 õpilast (10. klassis), kelle kognitiivse testiosa saavutused algavad 50\% võimalikust punktide arvust. See tase on ka kõige heterogeensem, kuna siia kuuluvad ka need õpilased, kelle saavutustase on üle 75\%. Tabelist 4 on näha, et õpilased liikusid tasemete vahel ka languse suunas, kuid nii 10. kui ka 12. klassis jäi enamik õpilasi siiski tasemetele 2 ja 3. Suurimad muutused on ühe taseme piires ja sellise muutuse hariduspoliitilise konteksti üle saab otsustada vaid tasemete sisulise analüüsi käigus, sest tasemetevaheline erinevus on vaid $10 \%$. 
Tabel 5. Õpilaste loodusteadusliku kirjaoskuse tasemete muutus gümnaasiumiõpingute jooksul

\begin{tabular}{|c|c|c|c|c|c|c|c|c|c|}
\hline & \multicolumn{7}{|c|}{ Loodusteadusliku kirjaoskuse tasemete muutus } & \multirow{3}{*}{$\begin{array}{l}\text { Kokku } \\
\text { õpilasi }\end{array}$} \\
\hline & & \multicolumn{7}{|c|}{ Õpilaste arv vastavalt taseme muutustele 12 . klassis } & \\
\hline & & -3 & -2 & -1 & 0 & 1 & 2 & 3 & \\
\hline \multirow{4}{*}{$\begin{array}{l}\text { Tase } \\
\text { 10. klassis }\end{array}$} & 1 & 0 & 0 & 0 & 79 & 98 & 34 & 22 & 233 \\
\hline & 2 & 0 & 0 & 107 & 193 & 95 & 79 & 0 & 474 \\
\hline & 3 & 0 & 62 & 177 & 103 & 104 & 0 & 0 & 446 \\
\hline & 4 & 8 & 45 & 59 & 70 & 0 & 0 & 0 & 182 \\
\hline \multicolumn{2}{|l|}{ Kokku } & 8 & 107 & 343 & 445 & 297 & 113 & 22 & 1335 \\
\hline
\end{tabular}

Märkus. Arv -3 näitab, et õpilane langes 10. klassiga võrreldes 12. klassis kolme taseme võrra.

\section{Arutelu}

\section{Gümnaasiumi lõpuklasside õpilaste loodusteadusliku kirjaoskuse tase}

Esmalt otsiti vastust küsimusele, milline on gümnaasiumi lõpuklasside õpilaste loodusteadusliku kirjaoskuse tase, mõõdetuna probleemide lahendamise ja otsuste tegemise oskuse, interdistsiplinaarsete teadmiste kasutamise oskuse, teaduse olemusest arusaamise ning enda oskuste hinnangu põhjal.

Kuivõrd tegemist oli Eestis esmakordse gümnaasiumiõpilaste loodusteadusliku kirjaoskuse tasemete hindamisega, eeldas uurimisrühm, et gümnaasiumiõpilaste saavutused, arvestades PISA väga häid tulemusi (OECD 2006, 2015), on aineteadmiste juurdekasvuga seoses edasi arenenud ka neis valdkondades, kus PISA 2006. aasta uuringus täheldati õpilaste tagasihoidlikke tulemusi. Eelduse aluseks oli 2010. aastal vastu võetud kompetentsuspõhine õppekava, mille rõhuasetus on "haridus läbi loodusteaduste“ (Holbrook \& Rannikmäe, 2007). Eesmärk on õpetada läbivaid teemasid kõigis õppeainetes ja kujundada laiemaid pädevusi (sh loodusteaduslikes õppeainetes). Õpilaste testimise tulemused kinnitavad, et aineteadmisi suudab uues situatsioonis reprodutseerida vaid pisut üle poole esimesse eksamigruppi kuuluvate koolide õpilastest, teistes eksamigruppides valdab seda oskust vähem kui pool vastanutest. Geograafia ainesisuga seotud ülesande puhul ilmneb 12. klassis kõikides eksamigruppides aineteadmiste reprodutseerimise oskuse vähenemine. Selle põhjus võib olla geograafiakursuste läbimine 10. ja 11. klassis: kui õppeaine ei kuulu enam tunniplaani 
ja oskus ei leia piisavalt rakendust, siis see väheneb aja jooksul. Üldjoontes ühtlustub õpilaste tase gümnaasiumiõpingute jooksul, kuid jääb siiski madalaks - vaid kolmandik õpilastest on ettenähtud oskuse omandanud. Siit tekib küsimus, mis toimub klassiruumis ja millele on suunatud teadmiste kontroll ning kas õpetajad on teadlikud probleemidest (Gilbert, 2006; Laius et al., 2016; Sjöström, 2013). Samuti tekib küsimus, kuidas tõlgendatakse praktikas loodusteadusliku kirjaoskuse määratlust: kas Robertsi I visiooni (Roberts, 2007) järgi või uue kompetentsuspõhise õppekava ja Robertsi II visiooni järgi? Kuna uurimistöö tulemused näitasid, et erinevate eksamitulemustega kooligruppide õpilaste saavutuste vahel ei ole selgeid erinevusi, jääb arutelu objektiks ka see, milliste teadmiste ja oskuste hindamisele oli suunatud lõpueksamite süsteem, millest juhindusid ka loodusteaduslike õppeainete õpetajad, ja kas see on kooskõlas ühiskonna nõudmistega 21. sajandi oskustele, mille hulgas on ka sotsiaal-teadusliku põhjendamise oskus (Choi et al., 2011; Holbrook \& Rannikmäe, 2009; Romine et al., 2017).

Interdistsiplinaarsete teadmiste kasutamise suhteliselt vähene oskus (veidi üle kolmandiku õpilastest on saavutanud selle oskuse gümnaasiumi lõpuks) on vastuolus õppekava eesmärkidega, kus rõhutatakse, et gümnaasiumilõpetaja kasutab loodusteaduslike õppeainete tundides omandatud süsteemseid teadmisi nähtuste ja protsesside selgitamisel ning loodusteaduslike, tehnoloogiaalaste ja sotsiaal-teaduslike probleemide lahendamisel (Gümnaasiumi riiklik õppekava, 2011). Nii ühe õppeaine kontekstis omandatud teadmiste reprodutseerimine kui ka interdistsiplinaarsete teadmiste rakendamine on ainespetsiifilised (Soobard, 2015), seejuures annavad õpilased osaliselt õigeid, sh väärarusaamasid sisaldavaid vastuseid. Võrreldes õpilaste teadmisi ja oskusi keskmiste alusel, jäävad need aspektid aga märkamatuks. Teave, mis õpetajani jõuab, ei võimalda neil edaspidises õppetöös valida sobivamaid õpetamismeetodeid, mida Laugksch (2000) ja Van Eijck (2012) peavad loodusteadusliku kirjaoskuse kujundamise seisukohalt oluliseks.

Muret tekitab loodusteadusliku sisuga probleemide lahendamise oskuste kujunemise protsess gümnaasiumis. Loodusteadusliku kirjaoskuse tasemete puhul (Bybee, 1997; Rannikmäe \& Soobard, 2014) jõuab praeguste uurimistulemuste põhjal maksimaalselt viiendik õpilastest loodusteadusliku kirjaoskuse strukturaalse tasemeni. Ka ei paranda olukorda osaliselt õige probleemilahenduseni jõudnud õpilaste osakaal. Seega on probleemide lahendamise oskus gümnaasiumi vanuseastmel pigem bipolaarne - see kas on omandatud või mitte - ja sõltub vähe probleemi olemusest. Selles valdkonnas eri eksamigruppidesse kuuluvate koolide õpilaste tasemed 
ühtlustuvad gümnaasiumiõpingute jooksul, millele viitab statistiliselt oluliste erinevuste vähenemine või kadumine 12. klassi õpilaste tulemustes.

Otsuse tegemisega seotud oskused on 10. klassis tagasihoidlikud, paranedes küll veidi 12 . klassis ( $c$ a $5 \%$ piires), kuid ei jõua siiski gümnaasiumi riiklikus õppekavas (2011) esitatud õpitulemusteni. Pigem jäävad need oskused 10. klassi alguse tasemele. Taas tekib küsimus: mis toimub gümnaasiumis? Kas loodusteaduslikku kirjaoskust kujundatakse Robertsi (2007) I või II visiooni alusel? Mil määral on sotsiaal-teaduslike probleemide käsitlemine õppetöö integratiivne osa ja kas õppetöö toetab ka rahvusvaheliselt aktsepteeritud metakognitiivsete oskuste kujundamist (Baartman \& Ruis, 2011; Tytler, 2014). Uuringu tulemused kinnitavad, et loodusteadusliku kirjaoskuse kujundamisel tuleb liikuda ainesisule orienteeritud kognitiivsete oskuste hindamise juurest metakognitiivsete oskuste kujundamise ja hindamise juurde (Choi et al., 2011). Kui õpilased olid suutelised andma adekvaatse hinnangu probleemide lahendamise oskusele, nagu ilmnes ka kontekstipõhise testi tulemustest, siis otsuse tegemise oskuse kõrgemalt hindamine võib olla seotud ka sellega, et seda pole loodusainete tundides tavapäraselt hinnatud (Soobard, 2015) ja õpilastel puudub võrdlus oma tegelike oskustega. Samas võiks eeldada, et kolme aasta jooksul toimub muutus ka õpilaste hinnangutes, kuna õppekavaga sätestatakse eelnimetatud oskuste kujundamise vajadus kõigis gümnaasiumiklassides. Muutust õpilaste hinnangutes oma metakognitiivsetele oskustele aga ei esine, mis osutab, et nende oskuste kujundamisele pööratakse vähest tähelepanu.

Kahjuks viitavad uuringu tulemused, et õpetamisel on rõhk teadmiste reprodutseerimisel, mitte probleemide lahendamise ja otsuste tegemise oskuste kujundamisel (Sadler \& Zeidler, 2005; Soobard \& Rannikmäe, 2015). Tabel 1 kinnitab PISA tulemusi, mille alusel on Eesti õpilased madalamat järku oskuste omandamisel kõrgel tasemel: 10. klassis korrektseid vastuseid andnud õpilaste protsent madalamaid oskusi mõõtvate ülesannete korral on kõrgem kui kõrgemat järku oskusi eeldavate küsimuste korral. 12. klassis võib täheldada sama tendentsi. Eriti tuleb see esile keemiaga seotud küsimustele vastamisel, mis viitab, et õppeaine tunnid on ainekesksed ning seal pööratakse vähe tähelepanu interdistsiplinaarsusele.

Kuidas aga suhestub õpilaste arusaam teaduse olemusest kõige eelnevaga? Gümnaasiumiastmel varasemad selletaolised suuremad uuringud puuduvad ja uurimisrühm eeldas Rannikmäe ja Rannikmäe (2014) juhtumiuuringutele tuginedes, et gümnaasiumiõpilased on erinevalt õpetajatest pigem relativistlike või konstruktivistlike arusaamadega. Praegused uurimistulemused aga näitasid, et ka õpilaste põhjendustes tuleb esile positivistlik tendents ja seda eriti teaduse olemuse aspektides, mida vahetult 
koolitundides ei käsitleta. Tõsi, õpilaste arusaamad üksikväidete puhul küll muutuvad, kuid on siiski juhusliku iseloomuga - üleüldine tendents lähtuda positivistlikest arusaamadest (Wellington, 2000 järgi valmistõdede uskumine ja kasutamine põhjendamisel) säilib. Kuigi Lederman jt (2002) on väitnud, et mitte kõik teaduse olemusega seotu ei ole õpilastele jõukohane mõista, rõhutab Tytler (2007), kuivõrd oluline on loodusteadusliku kirjaoskuse seisukohalt mõista teaduse olemust.

Õpilased ei erista pseudoteadust ja teadust. Samas Sjøbergi ja Schreineri (2002) järgi on pseudoteaduslikud nähtused õpilaste jaoks huvitavad. Oma seisukohtade põhjendamisel kasutavad õpilased igapäevaelust meelde jäänud positivistlikke fragmente ja teevad loogikavigu, tuginedes tihti analoogiale või tavakogemusele. Pseudoteaduse ja teaduse vahekorra käsitlemisel puudub õpilastel kindel arusaam. Näiteks eristades astroloogiaga seotud pseudoteaduslikke nähtusi teaduslikest, kasutavad õpilased põhjendamisel fragmente kooliõpikutest ja sellele tuginevat konstruktivistlikku õpikäsitust (Rannikmäe \& Rannikmäe, 2014).

\section{Õpilaste oskus seostada mõisteid ja moodustada lauseid}

Järgmisena otsiti vastust uurimisküsimusele, kuidas muutub gümnaasiumiõpingute jooksul õpilaste oskus seostada mõisteid ja moodustada nendest lauseid.

Reiska ja Soika (2015) leiavad, et konstrueeritud lausete arv on oluline õpilaste mõistekaardi kvaliteedi näitaja, mis korreleerub näiteks erialaselt korrektsete lausete arvuga mõistekaardis. Mõistekaartide konstrueerimisel moodustasid õpilased 12. klassis küll mõnevõrra enam lauseid kui 10. klassis, kuid mõistekaartide üldist struktuuri näitav taksonoomia tase väga palju ei muutunud.

Mõistekaartide konstrueerimine on ühelt poolt seotud õpilaste olemasolevate kognitiivsete struktuuride kasutamisega tundmatus kontekstis (Bramwell-Lalor \& Rainford, 2013), teisalt eeldab see kontekstipõhise fookusega ülesande korral (Novak \& Cañas, 2008) ka reaalelulise situatsiooni kontekstualiseerimist, mis seostub probleemi nägemise oskusega (Holbrook \& Rannikmäe, 2009).

Õpilaste oskus seostada omavahel eri mõisteid (eelkõige eri ainevaldkondadesse kuuluvaid mõisteid) suurenes gümnaasiumi jooksul vaid vähesel määral. Tuginedes Reiska ja Soika (2015) uurimusele, võib sellega seletada ka õpilaste väikest probleemide lahendamise oskust, mis hõlmab mõistetevaheliste seoste loomist. Loodusteadusliku kirjaoskuse kõrgematel tasemetel olevad õpilased oskavad luua enam seoseid mõistete vahel (esines korrelatsioon mõistekaardi tunnuste ja loodusteadusliku kirjaoskuse 
tasemete vahel). Seda kinnitavad ka varasemad uuringud, mis näitavad korrelatsiooni õpilaste loodusteadusliku kirjaoskuse testi osade ja mõistekaartide tunnuste vahel (Soika \& Reiska, 2014). Sellest võib järeldada, et mõistekaardi meetodi abil on teatud reservatsiooniga võimalik ennustada õpilaste loodusteadusliku kirjaoskuse taset.

\section{Õpilaste loodusteadusliku kirjaoskuse taseme muutumine}

Järgnevalt uuriti, kuidas muutub õpilaste loodusteadusliku kirjaoskuse tase gümnaasiumis õppimise jooksul. Testis, millega mõõdeti õpilaste kõrgemat järku oskusi (nt probleemide lahendamine, otsuste tegemine ja põhjendamine, interdistsiplinaarsete teadmiste kasutamine teaduslikul selgitamisel), jäid 10. ja 12. klassi võrdluses õpilaste tulemused muutumatult alla 50\% maksimaalsest punktide arvust. See tõsiasi viitab sellele, et kõrgemat järku oskuste kujundamisele pööratakse gümnaasiumiastmes vähe tähelepanu ja seega piirdub loodusteadusliku kirjaoskuse määratlus Robertsi (2007) I visiooniga, mis seostub ka TIMMSi testide filosoofiaga.

Kuna loodusteaduslik kirjaoskus ei ole ajas muutumatu kontseptsioon (Bybee, 1997; Holbrook \& Rannikmäe, 2009), töötati praeguses uurimuses välja metoodika, mis võimaldab esitada gümnaasiumi jooksul toimuvaid loodusteadusliku kirjaoskuse tasemete muutusi, võttes arvesse nii kvantitatiivselt mõõdetavaid suurusi kui ka kvalitatiivseid metakognitiivseid aspekte õpilaste vastustes. Seejuures on oluline näidata õpilaste tasemete vahelist liikumist, et prognoosida paradigmaatiliste muutuste vajalikkust loodusteaduslike õppeainete õpetamisel gümnaasiumis (Holbrook, 2008). Kuivõrd enamiku õpilaste tulemused on alla $50 \%$ maksimaalsest punktide arvust, ei saa siinkohal eristatud tasemeid võrrelda samal skaalal Bybee (2007) tasemetega, kus kõrgeim ehk mitmedimensiooniline tase iseloomustab kõigi 21. sajandil toimetulekuks vajalike oskuste omandatust. Loodusteadusliku kirjaoskuse tasemete testi tulemuste alusel saadud õpilaste loodusteadusliku kirjaoskuse tasemete muutuse dünaamikal on teaduslik-rakenduslik väärtus, sest see võimaldab arvestada heterogeensust ja määrata kindlaks selle põhjused gümnaasiumi vanuseastmel.

Taseme languse korral võivad muutuste põhjused seostuda näiteks loodusteaduslike õppeainete, nt keemia vähese tundide arvuga gümnaasiumis või mõne aine tundide puudumisega 12. klassis. Eesti kontekstis 10. klassis loodusteadusliku kirjaoskuse kõrgeimal tasemel olevast 182 õpilasest on rohkem kui pooled teinud gümnaasiumi jooksul läbi tasemelanguse. Bennetti ja tema kolleegide (2007) ning Feinsteini (2010) järgi võiks eeldada kõrgemat järku oskuste tõusu (seega ka õpilaste liikumist kõrgematele loodusteadusliku kirjaoskuse tasemetele) gümnaasiumi 
jooksul, juhul kui sage kontekstipõhine hindamine klassiruumis on seotud õpilastele tähendusrikaste situatsioonidega. Praegused uurimistulemused ei kinnita sihipärast kontekstipõhist hindamist loodusteaduslike ainete tundides. Kuigi enim õpilasi jääb keskmistele loodusteadusliku kirjaoskuse tasemetele, on oluline pöörata tähelepanu ka neile, kes jäävad äärmuslikele tasemetele: tugevamatele õpilastele tuleks pakkuda võimalust panna proovile oma teadmisi ja oskusi, kuid need 20\% õpilastest, kes jäid loodusteadusliku kirjaoskuse tasemete tõusust hoolimata endiselt madalaimale tasemele, vajavad varasemast tugevamat toetust.

\section{Järeldused}

1. Kuna gümnaasiumiõpilaste oskus aineteadmisi reprodutseerida on õppeainespetsiifiline (suurim bioloogias, väikseim keemias), kuid olulisi erinevusi 10. ja 12. klassi õpilaste oskuste vahel ei esine, võib järeldada, et traditsiooniliselt on loodusteaduslike õppeainete õpetamisel rõhuasetus reprodutseeritavate teadmiste hindamisel (tunni kontekstis). Hindamisel ei lähtuta õppekava eesmärkidest ja see pärsib loodusteadusliku kirjaoskuse kujundamist Robertsi (2007) II visiooni suunas.

2. 10. ja 12. klassi õpilaste kõrgemat järku kognitiivsed oskused on samal tasemel: vaid neljandik õpilasi on omandanud oskuse lahendada loodusteadusliku sisuga probleeme, interdistsiplinaarsete teadmiste kasutamisel on raskusi enam kui pooltel õpilastel, otsuse tegemise oskuse on omandanud vaid kümnendik õpilastest. Seegi viitab asjaolule, et õpetamisel ei ole rõhuasetus mitte kompetentsuse kujundamisel, nagu uues õppekavas see on sätestatud, vaid endistviisi domineerib õpikumaterjali edastamine õpilastele ja teadmiste kontroll järgib endiselt riigieksamitesarnast kontseptsiooni, kus kujundaval hindamisel ei ole kohta.

3. Teaduse olemuse mõistmisel, mida kontrolliti pseudoteaduse ja teaduse vahekorra määratlemise küsimustega, statistilist erinevust 10 . ja 12. klassi õpilaste vahel ei täheldatud. See viitab, et eelnimetatud temaatikale pööratakse vähe tähelepanu ja gümnaasiumi vanuseastmel rakendatakse positivistlikku õpetamisstiili. Sellega võib seletada ka seda, miks õpilased kasutavad positivistlikke põhjendusi.

4. Õpilaste hinnangul on nende oskused probleemide lahendamisel pigem väikesed, mõnevõrra kõrgemalt hindavad õpilased ennast interdistsiplinaarsete teadmiste rakendamisel ja otsuste tegemisel. See viitab rõhuasetustele hindamisel. Oskustele, mida loodusteaduste tundides hinnatakse, annavad õpilased metakognitiivsel tasandil õigema hinnangu. 
5. Kontekstipõhised valideeritud kompleksinstrumendid võimaldavad hinnata õpilaste loodusteadusliku kirjaoskuse hetketaset ja selle muutust ópingute jooksul Robertsi II visiooni suunas.

6. Mõistekaardi meetodi kasutamine loodusteadusliku kirjaoskuse hindamisel võimaldab prognoosida, kuidas õppija konstrueerib teadmisi ja kuidas need on seotud kõrgemat järku kognitiivsete oskuste omandamisega reaaleluliste situatsioonide näitel.

7. Uuringu raames väljatöötatud programm mõistekaartide analüüsimiseks võimaldab anda uut informatsiooni õpilaste teadmiste kohta, sh selle kohta, milline on õpilaste loodud mõistekaartide struktuur ja selle muutus gümnaasiumi jooksul.

8. Õpilaste loodusteadusliku kirjaoskuse tase tõuseb gümnaasiumi jooksul minimaalselt (see tõus ei ole statistiliselt oluline). Tegemist on pigem paigalseisuga. Vaja on alustada hariduspoliitilist diskussiooni loodusteaduslike õppeainete õpetamise nüüdisajastamiseks.

\section{Soovitused}

Tuleks mõelda, kuidas viia õpetamine ja õppimine selleni, et õpilaste loodusteadusliku kirjaoskuse tase areneks kolme gümnaasiumiaasta jooksul senisest enam. Kindlasti seostub see sellega, kuidas ja mida loodusainete tundides hinnatakse. Uurimuse raames töötati välja põhimõtted ja evalveeriti kompleksinstrument loodusteadusliku kirjaoskuse tasemete mõõtmiseks gümnaasiumiastmes. Nendest põhimõtetest lähtudes on võimalik ka edaspidi kasutada gümnaasiumiõpilaste loodusteadusliku kirjaoskuse tasemete mõõtmiseks uudset ja mitte ainult teadmiste mõõtmiseks mõeldud testi. Loodusteadusliku kirjaoskuse tasemete test sobib ka loodusainete lõpueksamiks gümnaasiumis.

Et läheneda Robertsi (2007) loodusteadusliku kirjaoskuse II visioonile, mis on suunatud teadmistepõhise ühiskonna kodaniku kujundamisele ehk 21. sajandi oskuste igakülgsele arendamisele, on vaja senisest enam tuua komplekstesti väärtushinnangulisi ja ka karjääriteadlikkust suurendavaid aspekte ning lisada kujundava hindamisega seotud komponente, mis võimaldavad anda hinnangut elluastuja vahetult testimatutele pädevustele (nt koostöö- ja meeskonnatööoskus, initsiatiivikus, loovus, moraalsed ja eetilised tõekspidamised). Loodusteadusliku kirjaoskuse tasemete testi tulemused viitavad vajadusele uurida edaspidi, mis toimub klassis ja millele pööravad õpetajad hindamisel tähelepanu, võttes arvesse, et uue õppekava vastuvõtmisest on möödunud kuus aastat. 


\section{Tänusõnad}

Täname kõiki longituuduuringus osalenud koole ja õpilasi. Praegust uurimust finantseeriti SA Archimedes grandi NLOLO 0950 (LoTeGüm) raames.

\section{Kasutatud kirjandus}

Afonso, A. S., \& Gilbert, J. K. (2010). Pseudo-science: A meaningful context for assessing nature of science. International Journal of Science Education, 32(3), pp. 329-348. https://doi.org/10.1080/09500690903055758

Aikenhead, G. S., \& Ryan, A. G. (1992). The development of a new instrument: "Views on Science-Technology-Society" (VOSTS). Science Education, 76(5), 477-491. https://doi.org/10.1002/sce.3730760503

Ausubel, D. P. (1968). Educational psychology: A cognitive view. New York: Holt, Rinehart \& Winston.

Baartman, L., \& Ruijs, L. (2011). Comparing students' perceived and actual competence in higher vocational education. Assessment and Evaluation in Higher Education, 36(4), 385-398. https://doi.org/10.1080/02602938.2011.553274

Bennett, J., Lubben, F., \& Hogarth, S. (2007). Bringing science to life: A synthesis of the research evidence on the effects of context-based and STS approaches to science teaching. Science Education, 91(3), 347-370. https://doi.org/10.1002/sce.20186

Biggs, J. B., \& Collis, K. F. (1982). Evaluating the quality of learning: The SOLO taxonomy (Structure of the Observed Learning Outcome). New York: Academic Press.

Bolte, C., Streller, S., Holbrook, J., Rannikmae, M., Hofstein, A., Mamlok Naaman, R., \& Rauch, F. (2012). Introduction into PROFILES project and its philosophy. In C. Bolte, J. Holbrook, \& F. Rauch (Eds.), Inquiry-based Science Education in Europe: Reflections from the PROFILES Project (pp. 31-41). Berlin: Freie Universität Berlin. Retrieved from http://www.profiles-project.eu/res/Conference_2012/ PROFILES_Book_final_October2012.pdf.

Bramwell-Lalor, S., \& Rainford, S. (2013). The effects of using concept mapping for improving advanced level biology students' lower- and higher-order cognitive skills. International Journal of Science Education, 36(5), pp. 839-864. https://doi.org/10.1080/09500693.2013.829255

Brinkerhoff, J. L., \& Booth, G. M. (2013). The effect of concept mapping on student achievement in an introductory non-majors biology class. European International Journal of Science and Technology, 2(8), 43-72.

Bybee, R. W. (1993). Reforming science education: Social perspectives and personal reflections. New York: Teachers College Press.

Bybee, R. W. (1997). Toward an understanding of scientific literacy. In W. Gräber \& C. Bolte (Eds.), Scientific literacy: An international symposium (pp. 37-68). Kiel: Institute for Science Education at the University of Kiel.

Cañas, J. A., Bunch, L., Novak, J. D., \& Reiska, P. (2013). Cmapanalysis: An extensible concept map analysis tool. Journal for Educators, Teachers and Trainers, 4(1), $36-46$. 
Cañas, J. A., Novak, J. D., \& Reiska, P. (2015). How good is my concept map? Am I a good Cmapper? Knowledge Management \& E-Learning, 7(1), 6-19.

Carnap, R., Hahn, H., \& Neurath, O. (1973). The scientific world conception: The Vienna Circle. In M. Neurath \& R. S. Cohen (Eds.), Empiricism and sociology (pp. 299-318). Dordrecht: Kluwer.

Chen, S. (2006). Development of an instrument to assess views on nature of science and attitudes toward teaching science. Science Education, 90(5), 803-819. https://doi.org/10.1002/sce.20147

Choi, K., Lee, H., Shin, N., Kim, S.-W., \& Krajcik, J. (2011). Re-conceptualization of scientific literacy in South Korea for the 21st century. Journal of Research in Science Teaching, 48(6), 670-697. https://doi.org/10.1002/tea.20424

Cohen, J. (1988). Statistical power analysis for the behavioral sciences (2nd ed.). Hillsdale: Lawrence Erlbaum Associates.

Croasdell, D. T., Freeman, L. A., \& Urbaczewski, A. (2003). Concept maps for teaching and assessment. Communications of the Association for Information Systems, 12, 396-405.

Daley, B. J. (2004). Using concept maps with adult students in higher education. In A. J. Cañas, J. D. Novak, \& F. M. González (Eds.), Concept maps: Theory, methodology, technology (Vol. 1, pp. 183-190). Navarra: NovaText.

Feinstein, N. (2010). Salvaging science literacy. Science Education, 95(1), 168-185. https://doi.org/10.1002/sce.20414

Gilbert, J. K. (2006). On the nature of context in chemical education. International Journal of Science Education, 28(9), 957-976. https://doi.org/10.1080/09500690600702470

Gilbert, J. K., Bulte, A. M. W., \& Pilot, A. (2011). Concept development and transfer in context-based science education. International Journal of Science Education, 33(6), 817-837. https://doi.org/10.1080/09500693.2010.493185

Griffin, P., Care, E., \& McGaw, B. (2012). The changing role of education and schools. In P. Griffin, B. McGaw, \& E. Care (Eds.), Assessment and teaching of 21st century skills (pp. 1-45). London: Springer. https://doi.org/10.1007/978-94-007-2324-5_1

Gümnaasiumi riiklik õppekava (2011). Riigi Teataja I, 29.08.2014, 21. Külastatud aadressil https://www.riigiteataja.ee/akt/129082014021.

Hofstein, A., Eilks, I., \& Bybee, R. (2011). Societal issues and their importance for contemporary science education: A pedagogical justification and the state-of-theart in Israel, Germany and the USA. International Journal of Science and Mathematics Education, 9(6), 1459-1483. https://doi.org/10.1007/s10763-010-9273-9

Holbrook, J. (2008). Introduction: The need for change. Paradigm shifts in science education. In J. Holbrook, M. Rannikmäe, P. Reiska, \& P. Ilsley (Eds.), The need for a paradigm shift in science education for post-Soviet societies (pp. 7-24). Frankfurt am Main: Peter Lang.

Holbrook, J., \& Rannikmäe, M. (2007). The nature of science education for enhancing scientific literacy. International Journal of Science Education, 29(11), 1347-1362. https://doi.org/10.1080/09500690601007549

Holbrook, J., \& Rannikmäe, M. (2009). The meaning of scientific literacy. International Journal of Environmental \& Science Education, 4(3), 275-288. 
Keppens, J., \& Hay, D. (2008). Concept map assessment for teaching computer programming. Computer Science Education, 18(1), pp. 31-42.

https://doi.org/10.1080/08993400701864880

Khishfe, R., \& Lederman, N. (2007). Relationship between instructional context and views of nature of science. International Journal of Science Education, 29(8), 939961. https://doi.org/10.1080/09500690601110947

Kinchin, I. (2014). Concept mapping as a learning tool in higher education: A critical analysis of recent reviews. The Journal of Continuing Higher Education, 62(1), 39-49. https://doi.org/10.1080/07377363.2014.872011

Krajcik, J. (2011). Learning progressions provide road maps for the development and validity of assessments and curriculum materials. Measurement, 9(2-3), 155-158. https://doi.org/10.1080/15366367.2011.603617

Laius, A., Post, A., \& Rannikmäe, M. (2016). Determining support of Estonian stakeholders for a new competence-based science education curriculum. International Journal of Education and Information Technologies, 10, 14-24.

Laugksch, R. C. (2000). Scientific literacy: A conceptual overview. Science Education, 84(1), 71-94. https://doi.org/10.1002/(SICI)1098-237X(200001)84:1<71::AID-SCE6>3.0.CO;2-C

Lederman, N. G., Abd-el-Khalick, F., Bell, R. L., \& Schwartz, R. S. (2002). Views of nature of science questionnaire: Towards valid and meaningful assessment of learners' conceptions of the nature of science. Journal of Research in Science Teaching, 39(6), 479-521. https://doi.org/10.1002/tea.10034

McDonald, C. V. (2010). The influence of explicit nature of science and argumentation instruction on preservice primary teachers' views of nature of science. Journal of Research in Science Teaching, 47(9), 1137-1164. https://doi.org/10.1002/tea.20377

McDonald, C. V. (2017). Exploring nature of science and argumentation in science education. In B. Akpan (Ed.), Science education: A global perspective (pp. 7-44). Switzerland: Springer. https://doi.org/10.1007/978-3-319-32351-0_2

Murcia, K. (2009). Re-thinking the development of scientific literacy through a rope metaphor. Research in Science Education, 39(2), 215-229. https://doi.org/10.1007/s11165-008-9081-1

NGSS (2013). New Generation Science Standards. Retrieved from http://www.nextgenscience.org.

Novak, J .D. (2010). Learning, creating, and using knowledge: Concept maps as facilitative tools in schools and corporations. Journal of e-Learning and Knowledge Society, 6(3), 21-30.

Novak, J. D., \& Cañas, A. J. (2008). The theory underlying concept maps and how to construct and use them. Pensacola: Institute for Human and Machine Cognition (IHMC). Retrieved from http://cmap.ihmc.us/docs/theory-of-concept-maps.

OECD (2007). PISA 2006: Science competencies for tomorrow's world. Volume I: Analysis. Paris: OECD.

OECD (2016). PISA 2015 results (Vol. 1): Excellence and equity in education. Paris: OECD Publishing.

Partnership for 21st century skills. "Framework for 21st century learning" (s.a). Retrieved from http://www.p21.org/our-work/p21-framework. 
Rannikmäe, A., \& Rannikmäe, M. (2014). Teaduse olemus ja loodusainete õpetamine. M. Rannikmäe \& R. Soobard (toim.), Paradigmaatilised suundumused loodusainete õpetamisel üldhariduskoolis (lk 21-32). Tartu: Eesti Ülikoolide Kirjastus.

Rannikmäe, A., Rannikmäe, M., \& Holbrook, J. (2008). A paradigm shift in teachers: Recognising the nature of science as its' place in teaching. In J. Holbrook, M. Rannikmäe, P. Reiska, \& P. Ilsley (Eds.), The need for a paradigm shift in science education for post-Soviet societies (pp. 143-163). Frankfurt am Main: Peter Lang.

Rannikmäe, M., \& Soobard, R. (2014). Loodusteaduslik ja tehnoloogia-alane kirjaoskus ja selle erinevad tasemed. M. Rannikmäe \& R. Soobard (toim.), Paradigmaatilised suundumused loodusainete ópetamisel üldhariduskoolis (lk 11-20). Tartu: Eesti Ülikoolide Kirjastus.

Reiska, P., \& Soika, K. (2015). Suggestions for teacher education from concept mapping studies. Knowledge Management \& E-Learning, 7(1), 149-161.

Roberts, D. A. (2007). Scientific literacy/science literacy. In S. K Abell \& N. G. Lederman (Eds.), Handbook of research on science education (pp. 729-780). Mahwah: Lawrence Erlbaum Associates.

Roberts, D. A., \& Bybee, R.W. (2014). Scientific literacy, science literacy, and science education. In N. G. Lederman \& S. K. Abell (Eds.), Handbook of research on science education (Vol. III). New York: Routledge.

Romine, W. L., Sadler, T. D., \& Kinslow, A. T. (2017). Assessment of scientific literacy: Development and validation of the Quantitative Assessment of Socio-Scientific Reasoning (QuASSR). Journal of Research in Science Teaching, 54(2), 274-295. https://doi.org/10.1002/tea.21368

Ruiz-Primo, M. A. (2000). On the use of concept maps as an assessment tool in science: What we have learned so far. Revista Electrónica de Investigación Educativa, 2(1), 29-52.

Sadler, T. D., \& Zeidler, D. L. (2005). The significance of content knowledge for informal reasoning regarding socioscientific issues: Applying genetics knowledge to genetic engineering issues. Science Education, 89(1), 71-93.

https://doi.org/10.1002/sce.20023

Sadler, T. D., \& Zeidler, D. L. (2009). Scientific literacy, PISA, and socioscientific discourse: Assessment for progressive aims of science education. Journal of Research in Science Teaching, 46(8), 909-921. https://doi.org/10.1002/tea.20327

Sjøberg, S., \& Schreiner, C. (2002). ROSE handbook: Introduction, guidelines and underlying ideas. Retrieved from http://www.ils.uio.no/forskning/rose/documents/ROSE\%20handbook.htm.

Sjöström, J. (2013). Towards Bildung-oriented chemistry education. Science \& Education, 22(7), 1873-1890. https://doi.org/10.1007/s11191-011-9401-0

Soika, K., \& Reiska, P. (2013). Large scale studies with concept mapping. Journal for Educators, Teachers and Trainers, 4(1), 142-153.

Soika, K., \& Reiska, P. (2014). Assessing student's cognitive skills with concept mapping. 8th International Technology, Education and Development Conference (pp. 7033-7043). Valencia: IATED.

Soobard, R. (2015). A study of gymnasium students' scientific literacy development based on determinants of cognitive learning outcomes and self-perception (Doctoral dissertation). Tartu: Tartu University Press. 
Soobard, R., \& Rannikmäe, M. (2014). Upper secondary students' self-perceptions of both their competence in problem solving, decision making and reasoning within science subjects and their future careers. Journal of Baltic Science Education, 13(4), 544-558.

Soobard, R., \& Rannikmäe, M. (2015). Examining curriculum related progress using a context-based test instrument - A comparison of Estonian grade 10 and 11 students. Science Education International, 26(3), 263-283.

Tytler, R. (2007). Australian education review: Re-imagining science education engaging students in science for Australia's future. Victoria: ACER Press.

Tytler, R. (2014). Attitudes, identity, and aspirations toward science. In N. G. Lederman \& S. K. Abell (Eds.), Handbook of research on science education (Vol. 3, pp. 82-103). New York: Routledge.

Van Eijck, M. (2012). Capturing the dynamics of science in science education. In B. J. Fraser, K. G. Tobin, \& C. J. McRobbie (Eds.), Second international handbook of science education (Vol. 2, pp. 1029-1039). London: Springer. https://doi.org/10.1007/978-1-4020-9041-7_68

Wellington, J. (2000). Teaching and learning secondary science: Contemporary issues and practical approaches. London, New York: Springer. 
Lisa 1. Komplekstesti stsenaariumite ja nendega seotud ülesannete näited

\section{Stsenaarium A}

Surnumeri, kõige madalamal asuv veekogu, on kuulus turistide hulgas. Selles leidub 35 liiki soola, mis on keemiatööstuse (sh kosmeetika- ja farmaatsiatööstuse) oluline tooraine. Põllumajanduses kasutatakse rohkelt Jordani jõe vett, mis on ajalooliselt voolanud Surnumerre. Nende tegevuste tulemusena väheneb Surnumere pindala igal aastal.

Ülesanne tasemel SOLO I

Surnumere põhja läbib nihkemurrang. Milline geoloogiline nähtus võib nihkemurrangu tulemusena selles piirkonnas esineda?

a) vulkanism

b) maavärinad

c) mandrilise maakoore teke

d) mäestiku teke

Ülesanne tasemel SOLO IV

Tee otsus, millist majandustegevust sa soovitaksid Iisraelil arendada. Põhjenda oma vastust, tuues välja nii positiivsed kui ka negatiivsed tegurid.

a) keskenduda turismile ja säilitada Surnumere senine veetase

b) keskenduda kosmeetikatööstuste rajamisele

c) keskenduda põllumajandusele ja tagada kohalikele elanikele omakasvatatud toit 


\section{Stsenaarium B}

Sõbrad läksid mägedesse matkama. Mäe jalamil ööbiti majakeses, kus oli hästi sisustatud köök erineva tehnikaga (vt pilte). Sõpradel tekkis soov kohvi keeta. Vett sai õues asuvast suurest anumast. Üks sõpradest võttis keeduspiraali ja hakkas sellega tassitäit vett kuumutama. Teised otsustasid kasutada elektripliiti. Kuna vaja läks veel vaid kahte tassitäit vett, siis otsustasid nad kasutada väikest potti.

\section{Ülesanne tasemel SOLO II}

Kuidas toimiksid sõprade asemel sina, kui sul oleks vaja võimalikult energiasäästlikult kuumutada kolm tassitäit vett keemistemperatuurini? Vali ainult sobivaim variant.

\begin{tabular}{|c|c|c|c|c|}
\hline $\begin{array}{c}\text { 1. Suur pott } \\
\text { pliidil }\end{array}$ & $\begin{array}{c}\text { 2. Väike pott } \\
\text { pliidil }\end{array}$ & 3. Keeduspiraal & 4. Veekeetja & $\frac{\text { 5.Mikrolaine- }}{\underline{\text { ahi }}}$ \\
\hline & & & \\
\hline
\end{tabular}

Põhjenda oma valikut (võimalik on valida mitu õiget vastusevarianti).

1) See on kõige suurema võimsusega

2) See on kõige väiksema võimsusega

3) See muundab elektrienergia kõige väiksemate kadudega vee soojusenergiaks

4) Sellel on kõige väiksemad elektrienergia kaod

5) Sellel on kõige väiksemad soojusenergia kaod

6) See kuumutab vett igast küljest korraga

7) Sellel on kõige suurem kuumutav pind

Ülesanne tasemel SOLO III

Millised seadmed sa ostaksid kööki, kui sul oleks vaja keeta vett iga päev toidu valmistamiseks? Põhjenda oma valikut. 
Lisa 2. Erinevused 10. ja 12. klassi õpilaste kognitiivsete oskuste võrdluses eksamigruppide kaupa

\begin{tabular}{|c|c|c|c|c|c|c|c|c|}
\hline \multicolumn{2}{|l|}{ Oskused } & \multirow{3}{*}{\begin{tabular}{|c|} 
Klass \\
10
\end{tabular}} & \multicolumn{6}{|c|}{ Erinevused eksamigruppide vahel (ANOVA test) } \\
\hline & & & \multirow{2}{*}{\begin{tabular}{|c|} 
I ja II \\
$F=0,107$ \\
$p=0,006$ \\
\end{tabular}} & \multirow{2}{*}{$\begin{array}{c}\text { I ja III } \\
-\end{array}$} & \multirow{2}{*}{$\begin{array}{c}\text { I ja IV } \\
-\end{array}$} & \multirow{2}{*}{$\begin{array}{c}\text { II ja } \\
\text { III } \\
-\end{array}$} & \multirow{2}{*}{$\begin{array}{c}\text { II ja } \\
\text { IV } \\
-\end{array}$} & \multirow{2}{*}{\begin{tabular}{|c|} 
III ja IV \\
-
\end{tabular}} \\
\hline $\begin{array}{l}\text { Loodus- } \\
\text { teadusliku }\end{array}$ & Probleem 1 & & & & & & & \\
\hline sisuga & & 12 & - & - & - & - & - & - \\
\hline $\begin{array}{l}\text { lahendamine } \\
\text { (SOLO III) }\end{array}$ & Probleem 2 & 10 & $\begin{array}{l}F=0,207 \\
p=0,001\end{array}$ & $\begin{array}{l}F=0,185 \\
p=0,005\end{array}$ & $\begin{array}{l}F=0,252 \\
p=0,000\end{array}$ & - & - & - \\
\hline & & 12 & - & - & - & - & - & - \\
\hline \multirow{4}{*}{$\begin{array}{l}\text { Otsuse } \\
\text { tegemine } \\
\text { koos põhjen- } \\
\text { dusega } \\
\text { (SOLO IV) }\end{array}$} & \multirow[t]{2}{*}{ Otsus 1} & 10 & $\begin{array}{l}F=0,204 \\
p=0,000\end{array}$ & - & $\begin{array}{l}F=0,224 \\
p=0,000\end{array}$ & - & - & $\begin{array}{l}F=0,144 \\
p=0,020\end{array}$ \\
\hline & & 12 & $\begin{array}{l}F=0,218 \\
p=0,008\end{array}$ & $\begin{array}{l}F=0,216 \\
p=0,009\end{array}$ & $\begin{array}{l}F=0,220 \\
p=0,008\end{array}$ & - & - & - \\
\hline & \multirow[t]{2}{*}{ Otsus 2} & 10 & $\begin{array}{l}F=0,164 \\
p=0,007\end{array}$ & $\begin{array}{l}F=0,167 \\
p=0,015\end{array}$ & $\begin{array}{l}F=0,164 \\
p=0,006\end{array}$ & - & - & - \\
\hline & & 12 & - & - & - & - & - & - \\
\hline \multirow{4}{*}{$\begin{array}{l}\text { Inter- } \\
\text { distsipli- } \\
\text { naarsete } \\
\text { teadmiste } \\
\text { kasutamine } \\
\text { (SOLO II) }\end{array}$} & \multirow[t]{2}{*}{$\begin{array}{l}\text { Rakenda- } \\
\text { mine } 2\end{array}$} & 10 & - & $\begin{array}{l}F=0,212 \\
p=0,026\end{array}$ & - & - & - & - \\
\hline & & 12 & - & - & - & - & - & - \\
\hline & \multirow[t]{2}{*}{$\begin{array}{l}\text { Rakenda- } \\
\text { mine } 3\end{array}$} & 10 & - & $\begin{array}{l}F=0,192 \\
p=0,002\end{array}$ & - & - & - & - \\
\hline & & 12 & $\begin{array}{l}F=0,261 \\
p=0,009\end{array}$ & - & - & - & - & - \\
\hline \multirow{8}{*}{$\begin{array}{l}\text { Aine- } \\
\text { teadmiste } \\
\text { reprodut- } \\
\text { seerimine } \\
\text { (SOLO I) }\end{array}$} & \multirow[t]{2}{*}{ Teadmised B } & 10 & - & - & - & - & - & - \\
\hline & & 12 & - & - & - & - & - & - \\
\hline & \multirow[t]{2}{*}{ Teadmised G } & 10 & $\begin{array}{l}F=0,114 \\
p=0,048\end{array}$ & $\begin{array}{l}F=0,121 \\
p=0,038\end{array}$ & - & - & - & - \\
\hline & & 12 & $\begin{array}{c}F=-0,160 \\
p=0,022\end{array}$ & - & - & - & - & - \\
\hline & \multirow[t]{2}{*}{ Teadmised K } & 10 & $\begin{array}{l}F=0,314 \\
p=0,001\end{array}$ & $\begin{array}{l}F=0,462 \\
p=0,000\end{array}$ & $\begin{array}{l}F=0,347 \\
p=0,000\end{array}$ & - & - & - \\
\hline & & 12 & - & $\begin{array}{l}F=0,246 \\
p=0,016\end{array}$ & $\begin{array}{l}F=0,349 \\
p=0,000\end{array}$ & - & - & - \\
\hline & \multirow[t]{2}{*}{ Teadmised F } & 10 & - & - & - & - & - & - \\
\hline & & 12 & $\begin{array}{l}F=0,270 \\
p=0,016\end{array}$ & - & $\begin{array}{l}F=0,275 \\
p=0,019\end{array}$ & - & - & - \\
\hline
\end{tabular}

Märkus. Ainekavadepõhised teadmised: B - bioloogia, K - keemia, G - geograafia, F - füüsika. 
Lisa 3. Kaks erineval taksonoomia tasemel mõistekaarti
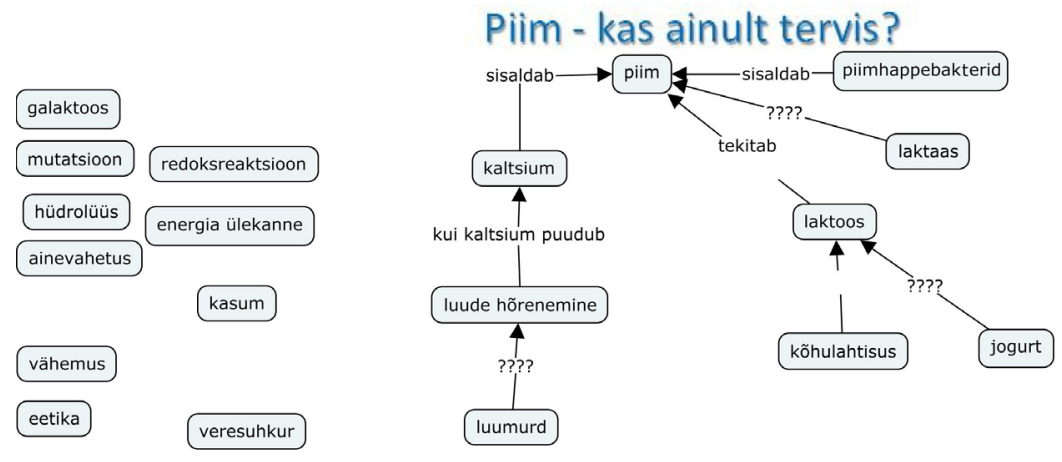

risk
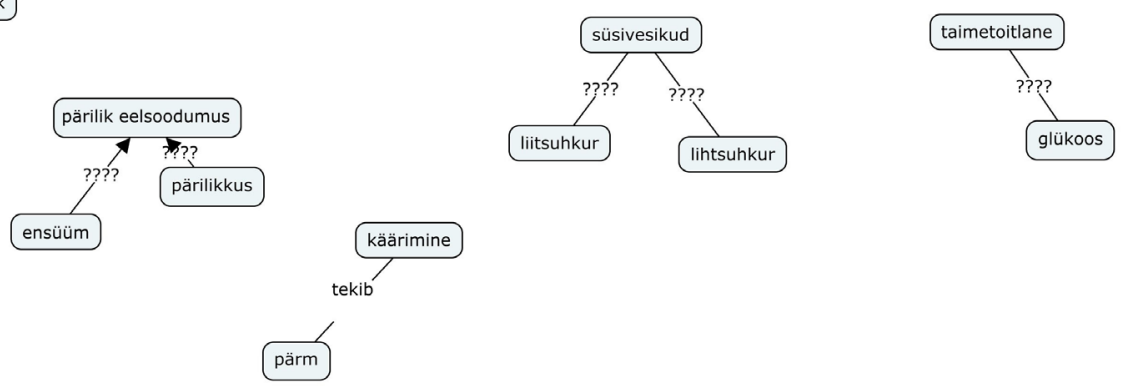

Mõistekaart taksonoomia tasemel 0

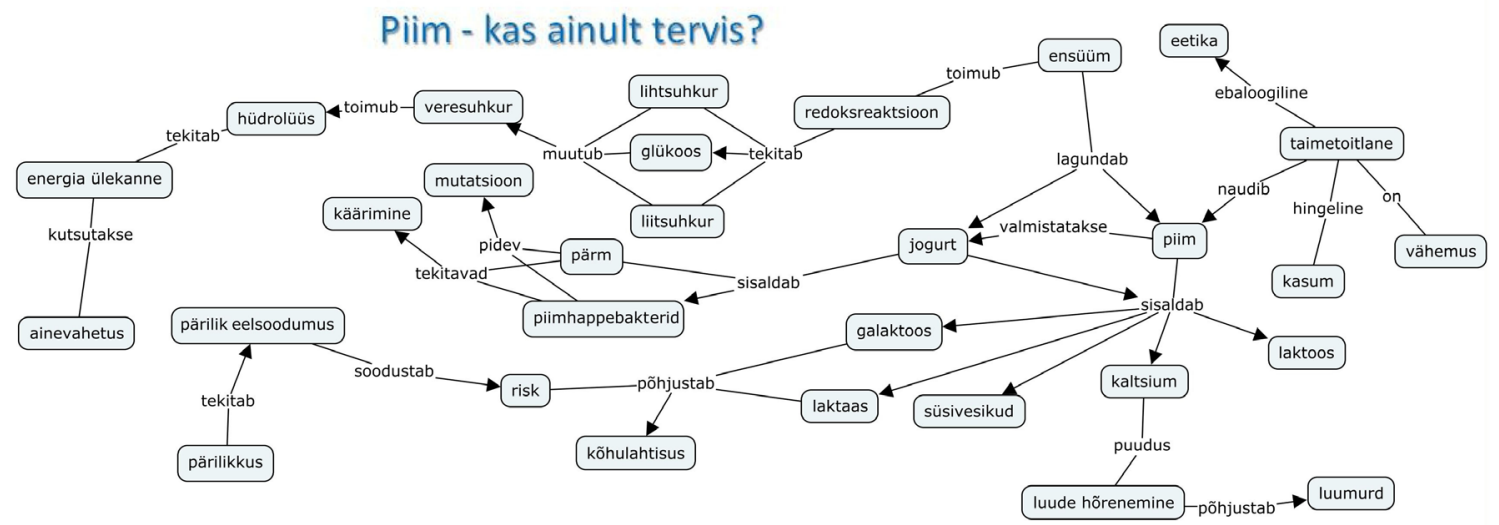

Mõistekaart taksonoomia tasemel 6 


\title{
The change in student scientific literacy levels during gymnasium studies
}

\author{
Miia Rannikmäe ${ }^{a 1}$, Regina Soobard $^{\mathrm{a}}$, Priit Reiska ${ }^{\mathrm{b}}$, \\ Arne Rannikmäe ${ }^{c}$, Jack Holbrook ${ }^{\mathrm{a}}$ \\ ${ }^{a}$ Centre for Science Education, University of Tartu \\ ${ }^{b}$ School of Natural Sciences and Health, Tallinn University \\ ${ }^{c}$ Centre for Legal and Social Sciences, Estonian Academy of Security Sciences
}

\section{Summary}

\section{Introduction}

Over the last decade, much of the research in science education has focused on measuring 14-15-year-old students' achievements and attitudes in learning science (OECD, 2007; TIMMS). For example, the PISA 2006 (OECD, 2007) international study, designed to test scientific literacy gains, showed that the performances of Estonian 15-year-old (grade 9) students were ranked highly (5th in the study), whereas their ability to solve problems and make decisions was at a lower level. Fewer studies have been conducted at the upper secondary level (Choi et al., 2011) and there are no similar PISA studies for students studying at higher grade levels.

The aims of this research:

1. To develop theoretically justified instruments for determining the levels of scientific literacy among gymnasium students.

2. To describe the development of scientific literacy promoted among students throughout gymnasium studies.

Research questions:

1. What is the level of scientific literacy among gymnasium students determined through problem-solving skills, reasoned decision-making skills, use of interdisciplinary knowledge skills, understanding the nature of science and student self-perceptions of competences measured?

2. How do students' concepts and phrases interlinking scientific and socioscientific concepts interrelate with learning skills associated with scientific literacy?

3. How do levels of scientific literacy change during gymnasium studies?

Centre for Science Education, University of Tartu, Vanemuise 46, 51014 Tartu, Estonia; miia.rannikmae@ut.ee 


\section{Theoretical background}

The overall goal of science education is seen as promoting scientific literacy (Roberts, 2007). For this study, scientific literacy (SL) is taken to mean developing an ability, to creatively utilise appropriate evidence-based scientific knowledge and skills, particularly with relevance for everyday life and a career, in solving personally challenging yet meaningful scientific problems, as well as making responsible socio-scientific decisions (Holbrook \& Rannikmäe, 2009). Everyday life and socio-scientific situations are usually complex. Any assessment of scientific literacy needs to relate to competences, based on those motivating students to give meaningful answers (Bennett et al., 2007), those where students utilise knowledge and skills for problem-solving and decision-making in real life (Feinstein, 2010; Holbrook \& Rannikmäe, 2007) and finally those related to shaping an accurate awareness of one's own competence (Baartman \& Ruijs, 2011). This indicates scientific literacy goes beyond cognitive learning and includes a self-perception component (Choi et al., 2011; Tytler, 2014).

Scientific literacy changes with time; it is not a continuum and depends on many factors, including students' age and interactions with society taking place outside the science classroom (Bybee, 1993). Bybee (1993) defines four levels of scientific literacy, which are expressed in wider terms than just a measurable achievement of students' cognitive outcomes. It is clear that for identifying the levels of SL, cognitive test and questionnaires are not sufficient. A range of updated and complex tools are needed.

In Estonia, at the gymnasium level, students compulsorily study science subjects, divided into biology, chemistry, physics and geography separately, and each subject is taught by a different teacher (Gümnaasiumi riiklik oppekava, 2011). However, the Estonian curriculum is competencebased and built around an internationally accepted philosophy of scientific literacy, with the separate science disciplines still expressed through curriculum sub-divisions. This raises the issue as to whether the teaching within each of the separate science subjects is equally promoting scientific literacy components, or students perceive these sub-divisions in different ways. Research carried out by the authors showed that the gymnasium students' ability to reproduce subject-related knowledge is subject specific, the highest being biology and lowest chemistry. Students also agree that science subjects develop the competence to recognise the importance of science in society, but disagree that science subjects, in general, focus on aspects of problem solving (Soobard \& Rannikmäe, 2014). 


\section{Methodology}

This research was the first systematic study to investigate the change of scientific literacy (SL) levels among Estonian gymnasium level students. A representative sample was composed of 2,216 students from 42 schools. Schools were chosen based on location (the capital; cities with at least two gymnasiums, and rural areas) and the students' mean national examination results within the school. Grade 10 students were tested again at the grade 12 level, when student number dropped to 2010. Throughout the 3 year period of the study, 1335 students participated at both levels.

An instrument was created for measuring the levels of SL. The originality of the research is linked to a multi-dimensional testing approach in four categories: cognitive (science skills and knowledge), philosophical (understanding the nature of science versus pseudoscience), attitudinal aspects and analytical (creating computer-based Cmaps). This research employs the use of Cmap techniques (Cañas et al., 2015) for triangulation of students' science cognitive learning outcomes and for modelling students' socio-scientifically conceptualised behaviour in real-life situations. The total instrument was administered in four parts.

Part 1 was a carefully constructed, contextualised test instrument, consisting of 4 interdisciplinary everyday life related scenarios, each focusing on one science subject (Biology, Chemistry, Geography, Physics) and to test the students' skills to give a scientific explanation, pose scientific questions, solve scientific problems, draw evidence based conclusions, interpret graphs and figures and to make reasoned decisions. Test item constructions followed the SOLO taxonomy (Biggs \& Collis, 1982). Students' responses were analysed using a three-point scale ( 0 - no or incorrect response, 1 - partial credit, 2 - full credit). Content validity was checked by expert opinion: four independent science teachers and four university science faculty staff members.

Part 2 was testing the students' understanding of the nature of science, including the students' ability to differentiate pseudoscience from science. Students expressed their agreements with the given statements, "agree" and "disagree." They were also asked to explain their answers. Students' reasoning was categorised into scientific, everyday-related and mistaken/ misconceptions. Categorisation was validated by independent experts.

Part 3 was testing self-perceptions against the skills important for scientific literacy using a 4-point Likert scale. The instrument was validated by using expert opinion.

For part 4, a Cmap instrument was linked with interdisciplinary scenarios from the cognitive test in part 1 . To create Cmaps, 30 different types 
(science processes, everyday social issues-related) of concepts were given to students. This part of the total instrument was used for triangulation and the number of students involved in this part was smaller. The results were analysed in terms of the total number of links between the concepts, structure and nature of central concepts and correctness of the sentences between the concepts.

The complex instrument was piloted among upper secondary school students who did not participate in the current study. Construct validity was undertaken by an analysis of Estonian gymnasium science curricula in the four subjects to ensure that the test instrument was valid in terms of its learning content and expected learning outcomes. The reliability, calculated using Cronbach alpha for section 1 was 0.85 , for section 2, 0.82 and for section 3,0.93. The first three parts were administered at the same time (90 min.). One scenario was kept the same for each student in both grade 10 and grade 12 testing, while the second scenario varied for every student. Cmap construction took place in a computer class ( $45 \mathrm{~min}$.) within 2 weeks following the first testing.

\section{Results and discussion}

Students' cognitive skills are at the same level among grade 10 and grade 12 students. However, the means are statistically different (the sample was large), although the overall mean values are relatively low and there is little increase. Although the mean score of higher order skills for grade 12 is notably low - in general, the ability of students' to solve problems remained at a low level even after two years of learning. These findings confirm that the warning messages from PISA studies (OECD, 2016) are being experienced at gymnasium level. Memorisation of science content and the use of interdisciplinary knowledge in student familiar situations achieve better results than higher order thinking skills. More detailed analyses show that approximately $60 \%$ of students fail to exhibit, or show very little change at the various skills levels, and at the same time there is little difference between those students whose scores have risen or fallen.

Thus the questions arising are: What is happening at gymnasium level? Are we to understand that all competences related to scientific literacy in the Estonian curriculum (Gümnaasiumi riiklik õppekava, 2011; Holbrook \& Rannikmäe, 2009) are being assessed? Were teachers following Robert's vision II, or only focusing their assessment along the lines of vision I? As there was almost no difference in grade 12 students test results between the school groups, compiled against the mean of the final examination results 
per school, it became obvious that the final school examination was targeted towards assessment of curriculum content. Analyses of Cmaps created by students showed a correlation between meaningful links formed between the concepts and cognitive test results, confirming the necessity to include this type of analytical measure into assessment tools (Soika \& Reiska, 2014). However, students' decision making and reasoning skills were poor (less than $20 \%$ of students exhibited excellence in this area), while students' selfperception of their metacognitive skills showed high attainment of these skills. From a positive viewpoint, students whose understanding of the nature of science, measured in terms of the type of reasoning, remained constant and were interchangeable among both grade levels (defined by Wellington, 2000).

Table 1 illustrates the differences at individual student levels, and shows that whilst there is no change of level among $30 \%$ of students, $40 \%$ of students change across only one level. The outcome of the study points to no statistical change in the levels of SL during grade 10 to 12 studies. This suggests that little learning is taking place beyond content knowledge and referencing, based on the Bybee (1997) description of levels of SL, and that most students remain at the structural and functional levels of SL. Our research confirms the need to concentrate on students with the lowest achievement levels, to push them to achieve at a higher level, and on students achieving at the highest level, to prevent them dropping to lower SL levels. However, the new competence-based curriculum, launched in 2011 (Gümnaasiumi riiklik õppekava, 2011), indicates the need for a paradigm shift in interpreting the curriculum and widening the scope of science teaching (Holbrook, 2008).

Table 1. Change of the levels of cognitive component of SL throughout the gymnasium studies where -3 is dropping 3 levels in grade 12 compared to grade 10

\begin{tabular}{l|r|r|r|r|r|r|r|r|r}
\hline \multicolumn{2}{c|}{} & \multicolumn{7}{c|}{ Change of SL } & \\
\cline { 2 - 10 } \multicolumn{2}{c|}{} & -3 & -2 & -1 & 0 & 1 & 2 & 3 & Total \\
\hline \multirow{3}{*}{$\begin{array}{c}\text { Level at } \\
10\end{array}$} & 1 & 0 & 0 & 0 & 79 & 98 & 34 & 22 & 233 \\
\cline { 2 - 10 } & 2 & 0 & 0 & 107 & 193 & 95 & 79 & 0 & 474 \\
\cline { 2 - 10 } & 3 & 0 & 62 & 177 & 103 & 104 & 0 & 0 & 446 \\
\cline { 2 - 10 } & 4 & 8 & 45 & 59 & 70 & 0 & 0 & 0 & 182 \\
\hline Total & 8 & 107 & 343 & 445 & 297 & 113 & 22 & 1335 \\
\hline
\end{tabular}


Outcome from the study points to no statistical change in the levels of SL from grade 10 to 12 .

\section{Further considerations}

During their gymnasium years, students' levels, related to SL cognitive components, show little change. If there is change, it is in content acquisition rather than in abilities in problem solving, or decision-making. Whilst it is important to teach the skills contained in the curriculum, teachers should pay more attention to promoting problem solving and the decisionmaking skills of the students.

There is a need to overcome the gap between the skills promoted in the different disciplines so that the education offered is seen as promoting the range of education goals, linked to the development of levels of scientific literacy. This is in line with the concept of more emphasis on interdisciplinary, 'education through science' rather than isolationism of subjects associated with 'science through education' (Holbrook \& Rannikmäe, 2007).

A new type of Cmap analysis is being developed for analysing student skills to create concept maps and a formula created for diagnosing students' levels of interdisciplinary knowledge using Cmaps. The outcomes suggested that there was a need to initiate discussion at the political level to seek ways to update the teaching of science in schools.

Keywords: scientific literacy, Cmaps, nature of science 